\title{
أدلة اثبات الصانع لدى الفرق الكلامية الإسلاهية -الشيعة ـ المعترلة ـ الاشعرية ـ أنموذجا-
}

أ.م.د.ابراهيهم موحاز تنابه

كلية الآداب . جامعة واسط

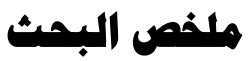

البحث: (أدلة اثبات الصانع لدى الفرق الكلامية الإسلامية الثيعة ـ المعتزلة ـ الاشعرية أنموذجا)، معني في

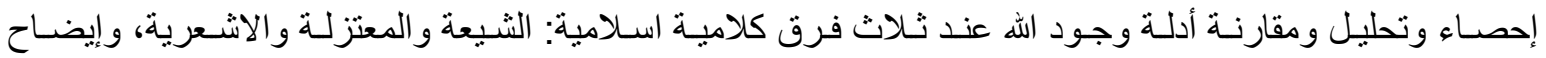
المنهجية التي سلكتها كل فرقة في إير اد أدلتها الخاصة و والمتعلقة بإثبات الصانع.

Abstract

Research: (Evidences of the Creator's Affirmation at Islamic Discourse Groups: Shia, Mu'tazila and Asha'ariya as Examples) It deals with counting, analyzing and comparing evidences of Allah's existence at three Islamic Discourse Groups: Shia, Mu'tazila and Asha'ariya. It explains the methodology adopted by each of these groups to present their proofs in verifying the Creator.

الإقدمة:

المتكلمون و هم قوم ندبو ا أنفسهم للخوض في (دقيق الكلام وجليله)( ( ) و العلم الذي عرفو ا بـه هو علم

الكلام و هو صناعة أو"ملكة بقتدر بها الإنسـان على نصرة الآر اء والأفعال المحدودة التي صر ح بها واضع الملة، وتزييف كل ما خالفها بالأقاويل، وهذه الصناعة تنقسم إلى جزءين: جزء هي الآر اءه وجزء في في الأفعال" (r) و المتكلمون كثر منهم (المعتزلـة و الأشـاعرة، والثيعة، و الخوارج، و المرجئة، و الباطنيـة...الخ) ويندرج

تحت كل واحدة من هذه فرق فرعية عديدة تتميز بفروق دقيقة عن المذهب العام الذي تندرج تحته (؟r).

تاريخيا لم تؤشر كتب التاريخ في حياة الرسول الأعظم محمد (صلى الله عليه وآله وسلم) إن هناك فرقاً

إسلامية إنما تذكر المصادر إن نشأة الفرق أصبحت بعد وفـاة النبي محمد فبعد مـا قبض رسول اللّ صلى الّّ عليه وآله في شهر ربيع الأول سنة عشر من الهجرة وهو ابن ثلاث وستين سنة وكانت نبوتهه عليه السـلام ثلاثا و عشرين سنة افترقت الأمـة تنلاث فرق فرقة منها سميت الثيعة وهم شيعة علي بن أبي طالب عليه السلام ومنهم افترقت صنوف الثيعة كلها وفرقة منهم ادعت الإمرة و السلطان وهم الأنصسار ودعوا إلى عقد الأمر لسعد بن عبادة الخزرجي وفرقة مالت إلى بيعـة أبي بكر بن أبي قحافة وتأولت فيه أن النبي صلى اللّه عليه و آله لم ينص على خليفة بعينه وأنه جعل الأمر إلى الأمة تختار لأنفسها من رضيته( ع) . يقول أبو الحسن الأشعري (ت كr rهـ) في معرض تحليله لأوضـاع المسلمين بعد وفاة نبيهم" اختلف

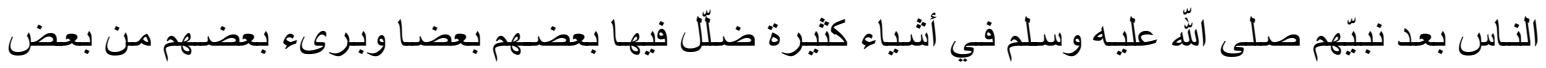

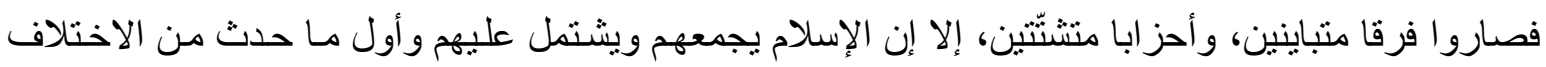

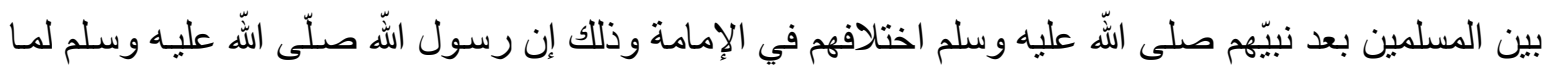

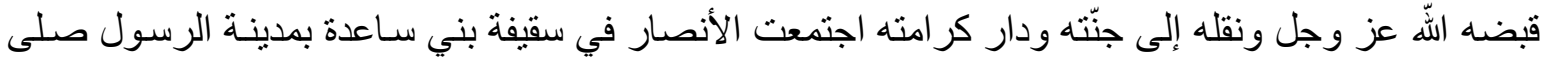

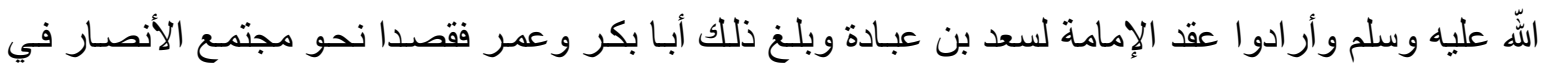


رجال من المهاجرين فأعلمهم أبو بكر إن الإمامة لا تكون إلا في قريش واحتجّ عليهم بقول النبيّ صلى الَّه

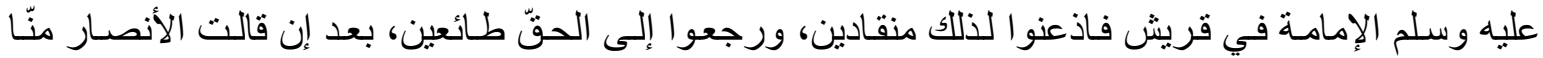

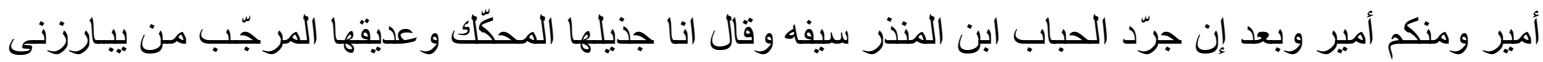

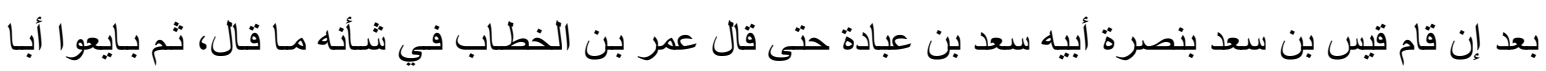

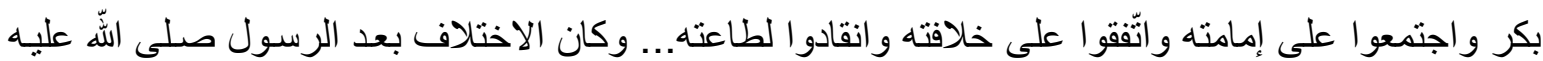

وسلم في الإمامة" (0). (0)

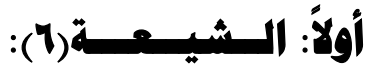

1. النشأة والتعريف:

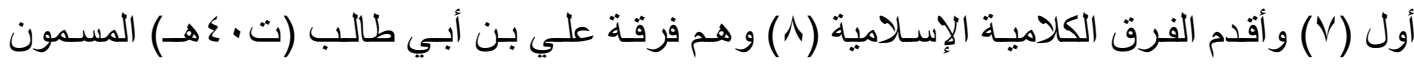

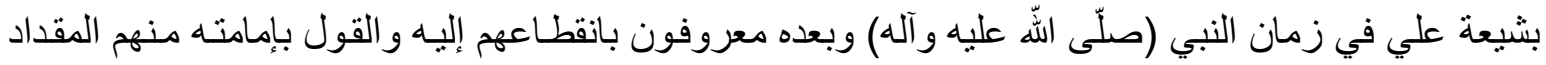

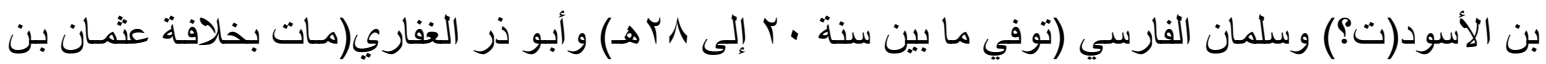

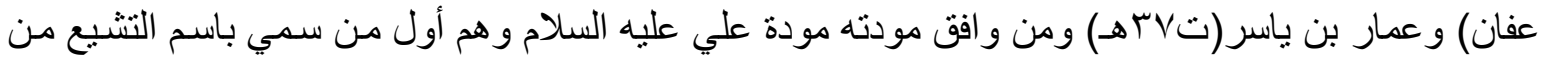

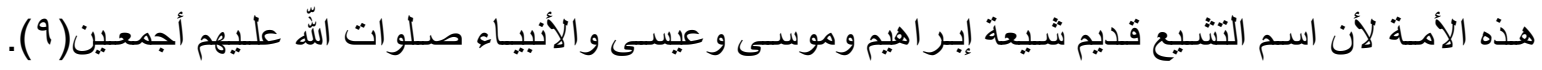

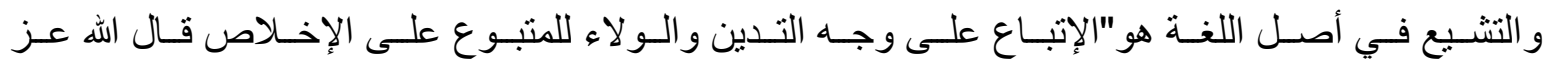

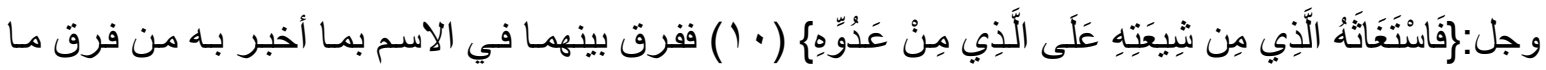

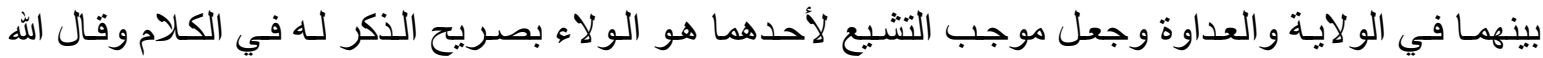

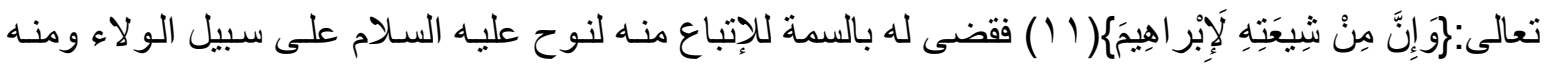

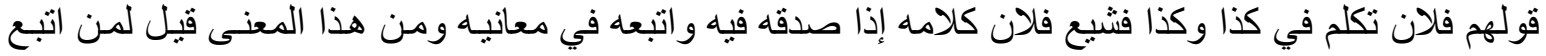
المسافر لوداعه هو مشيع له غير أنه ليس كل مشيع لغيره على حقيقة مـا ذكرناه من الإتباع يستحق السمة

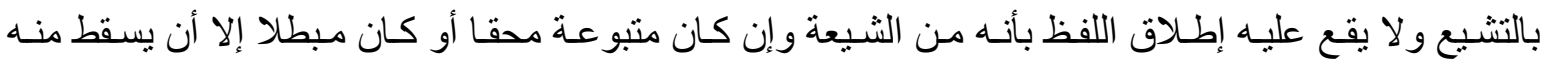

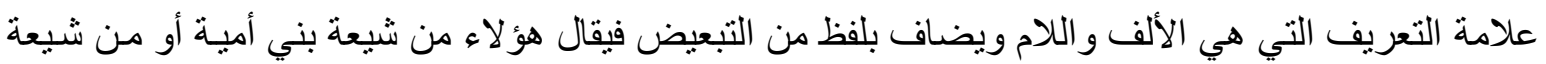

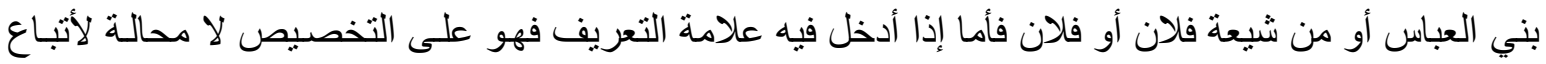

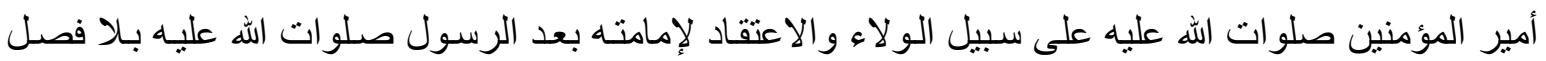
ونفي الإمامسة عمن تقدمه في مقام الخلافة وجعله في الاعتقاد متنو عا لهم غير تابع لأحد منهم على وجـها

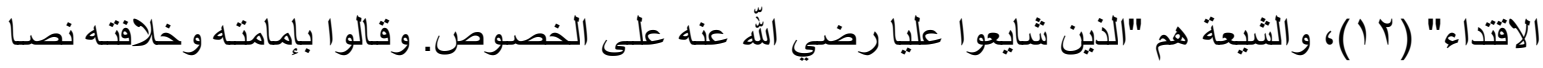

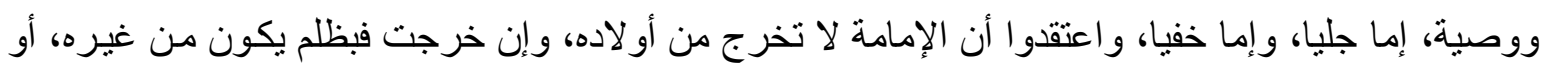

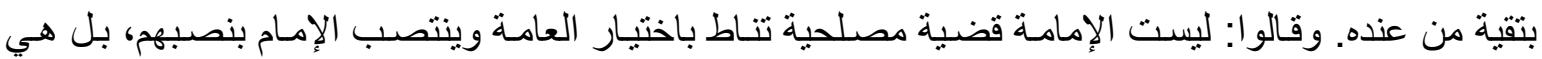

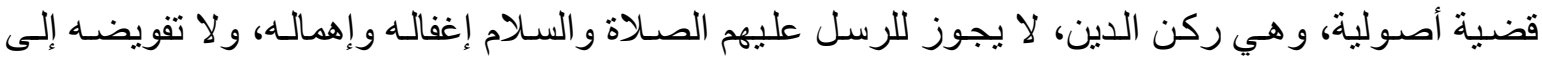

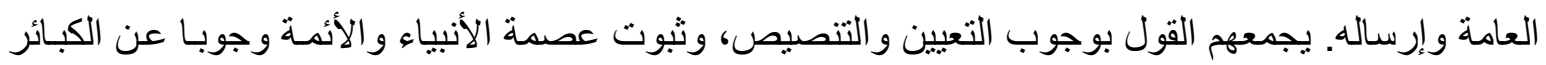

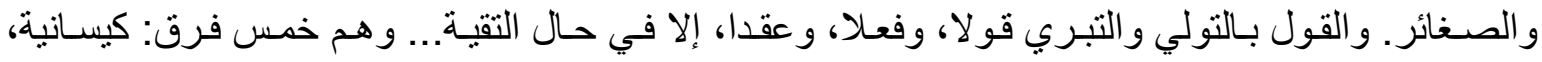

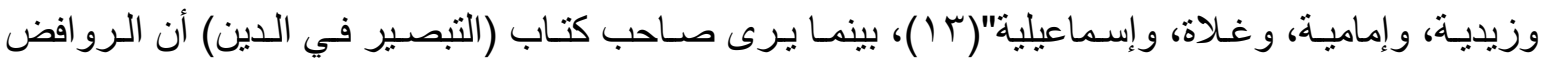


يجمعهم ثـلاث فرق: الزيديـة والأماميـة والكيسـانية( ( ) إمـا صـاحب كتاب (الفرق بين الفرق وبيـان الفرقة الناجية منهم) فيذكر إن الأمامية من الر افضة هؤ لاء الامامية المخالفة للزيدية و الكيسـانية والغلاة خمس عشرة فرقة:كاملية، ومحمدية، وباقرية، وناوسية، وشميطية، و عمارية، واسماعيلية، ومباركية، وموسوية، وقية وقطيعية، و اثنـى عثـرية، و هثـامية، وزراريـة، ويونسية، وشيطانية (0 1 ) إمـا صـاحب كتاب(التنبيـه و الردد على أهل الأهو اءو والبدع) فيرى إن الر افضة ثماني عثرة فرقة يلقبون بالأماميـة وأولهم الفرقة الغالية من السبئية وهم

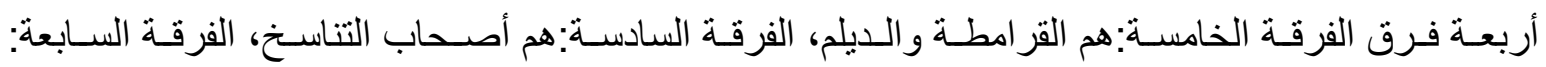

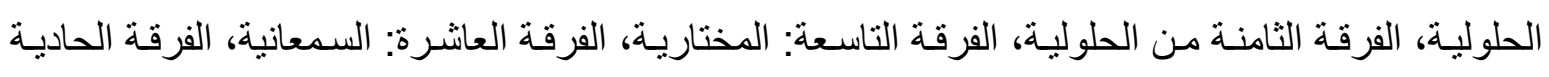
عشرة: الجارودية، الفرقة الثانية عشرة: الهثـامية، الفرقة الثالثة عشرة: الاسماعيلية، الفرقـة الرابعـة عشرة: أهل قم، الفرقة الخامسـة عشرة: الجعفريـة، الفرقـة السادسـة عشرة: القطعيـة العظمى، الفرقة السـابعة عشرة: القطعية القصرى، الفرقة الثامنة عشر:الزيدية (7 ( ) ويرى السيد محمد صادق آل بحر العلوم إن"الموجود من فرق الثيعة الآن(الأمامية الاثنا عشرية) والعبرة بهم وبكتبهم فحسب وهم منتشرون في أرجاء العالم(الزيديـة) في اليمن وضواحيها (الاسماعيلية) في الهند وغيره و أما الغلاة فهم عندنا كفار"( IV). م.أدلة وجود الله عندميم:

عنيت البشرية منذ تنسمت أول نسـائم الحياة على سطح الأرض بـالتفكير في خالق الحياة ومفيضـها على هذا الكون الرحيب وكان حديث الناس عن الإلوهية في تلك العصور المغرقة في القدم متماشيا مع مـا كانو ا عليه من فطر سـاذجة ومدارك محدودة وقابليات ذهنيـة ضيقة الأفق ثم توسع الحديث وتشـعب بفضل

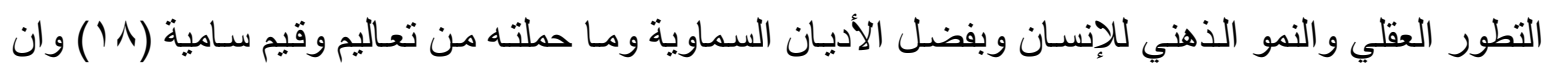
"العقل يدعو الإنسان العاقل ويحفزه إلى التفكر والبحث عن وجود اللّ تعالى. وذلك لأنّ هناك مجموعة كبيرة

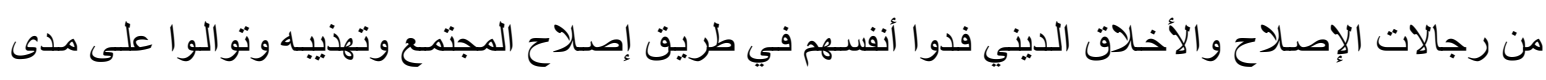

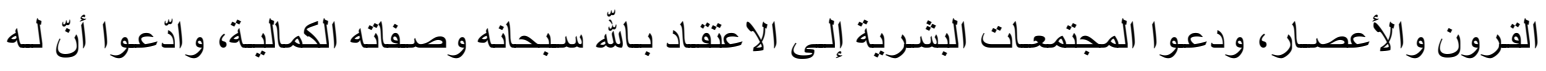

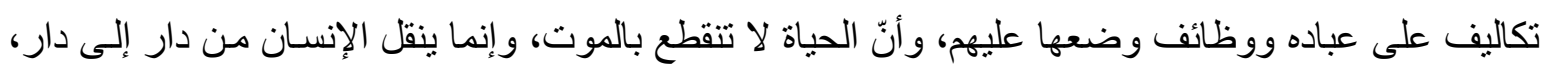

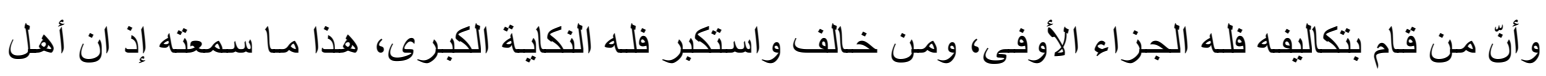

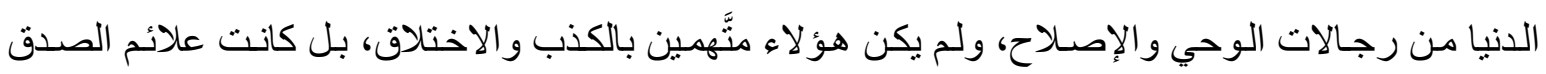
لائحة من خلال حياتهم و أفعالهم و اذكار هم، عند ذلك يدفع العقل الإنسان المفكّر إلى البحث عن صحَّة مقالتهم دفعاً للضرر المحتمل أو المظنون الّذي يورثه أمثال هؤلاء"( 9 و ). وان "أول الأفعال المقصودة التي لا يصح خلو العاقل منها وجوب النظر المؤدي إلى المعرفة يفرق ما بين الحق والباطل لأن كل عاقل نشأ بين العقلاء يعلم اختلافهم ودعوة كل فريق منهم إلى مذهبه وتخويفه من خلافه فيخـافهم لا محالـة و إذا خـاف وجب عليـه التحرز ممـا خافه لعلمـه ضـرورة بوجوب التحرز مـن الضرر فلا يخلو أن يتحرز باتباع الجل أو إطر اح الجل أو اتباع بعض عن نظر أو تقليد. و اتبـاع الحل محسال

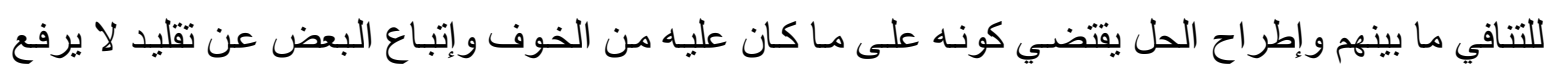
خوفه مما أطرحه من المذاهب لتجويز كونه حقا ولا يقتضي سكونه إلى مـا ذهب إليه لتجويز كونـه باطلا فلم 
يبـق لتحـرزه مـن الضـرر المخـوف إلا النظـر الميـز للحـق مـن الباطـل فوجـب فعلـه لكونـهـ تحـرزا مـن

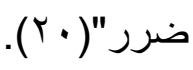

قال شيخ الطائفة أبو جعفر محمد الطوسي (ت . 7 ـهـ): "معرفة الله واجبة على كل مكلف، بدليل انه

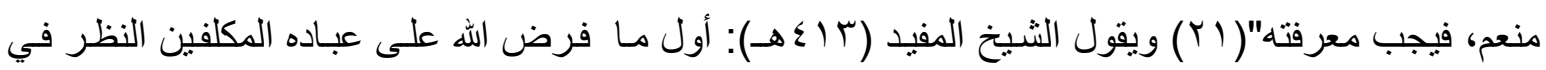
أدلته فإن قال: ما الدليل على ذلك فقل لأنه سبحانه قد فرض معرفته و لا سبيل إلى معرفته إلا بـالنظر في أدلته (Y ) ويرى العلامة الحلي (TYT هـ) أن معرفة الله تعالى واجبة بالعقل وأن وجوب معرفة الله تعالى مستفاد

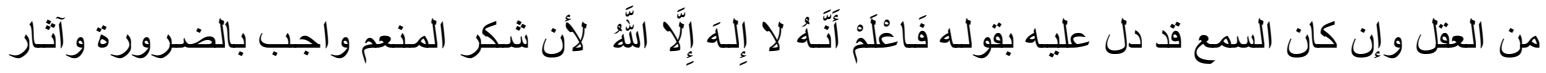

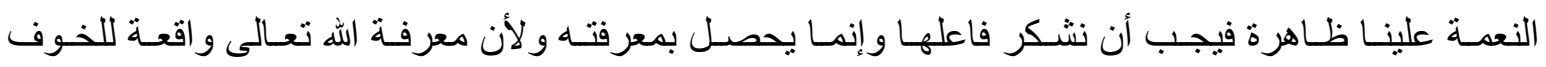

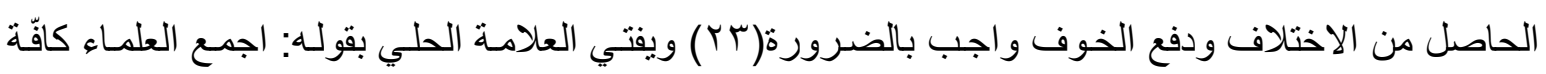

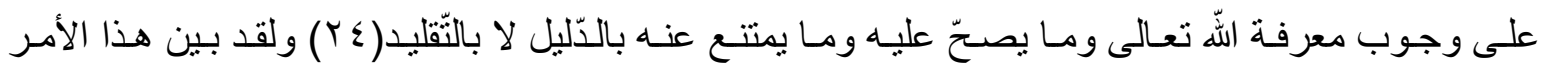

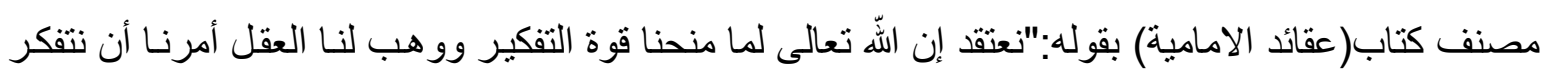
في خلقه وننظر بالتأمل في آثار صنعه ونتدبر في حكته و إتقان تدبيره في آياته في الآفاق وفي أنفسنا قال

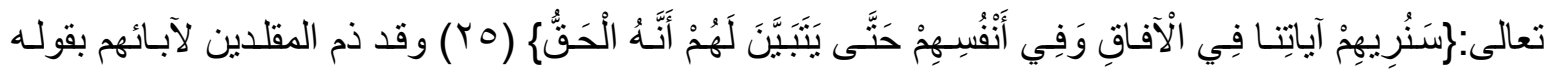

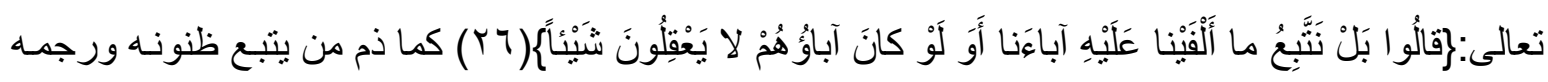

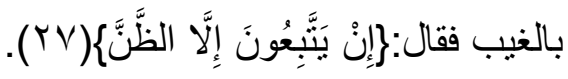

وفي الحقيقة أن الذي نعتقده "أن عقولنا هي التي فرضت علينا النظر في الخلق ومعرفـة خالق الكون، كما فرضت علينا النظر في دعوى من بدعي النبوة وفي معجزته، و لا يصـح عندنا تقليد الغير في ذلك مهما كان ذلك الغير منزلة وخطر ا وما جاء في القرآن الكريم من الحث على التفكير و إتباع العلم و المعرفة فإنما

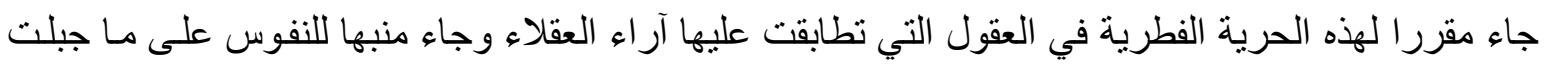

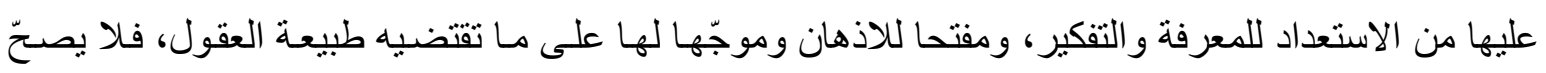

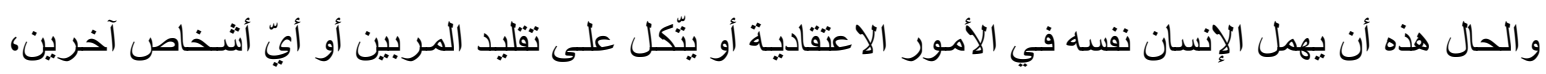
بل يجب عليه بحسب الفطرة العقلية المؤيدة بالنصوص القرآنية أن يفحص ويتأمل وينظر ويتدبر في أصول اعتقاداته المسماة بأصول الدين التي أهمها التوحيد... ومن قلّد آبـاءه أو نحوهم في اعتقاد هذه الأصدول فقد ارتكب شططا وز اغ عن الصر اط المستقيم ولا يكون معذورا أبدا، وبالاختصـار عندنا هنـا ادعاءان: الأول: وجوب النظر والمعرفة في أصول العقائد ولا يجوز تقليد الغير فيها. و الثاني: أن هذا وجوب عقلي قبل أن يكون وجوبـا شر عيا أي لا يستقي علمه مـن النصوص الدينية وإن كان يصـح أن يكون مؤيدا بها بعد دلالتة العقل وليس معنى الوجوب العقلي إلّا إدر الك العقل لضـرورة المعرفة ولزوم التفكير والاجتهاد في أصسول الاعتقادات" (r^) لذلك قدم الثيعة أدلة استدلالية عديدة لإثبات وجود الله تعالى منها:

\section{أ. العــدوث:}

وهو من أو ائلـ الأدلة التـي اسـتدل بها المسلمون (متكلمـون وفلاسفة) على وجـود الله ولهذا الدليل حضور واسع لدى الثيعة خلال التاريخ ولعل السبب بذلك هو إهتمام أئمة أهل بيت النبوة بهذا الدليل فلقد ورد 
كثبراً في خطبهم ومقو لاتهم ويمكنتا القول إن أول إنشارة لهذا الدليل في تاريخ الفكر الإسلامي وردت في

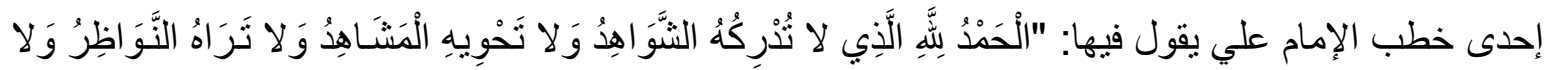

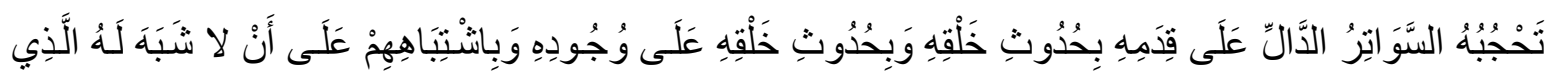

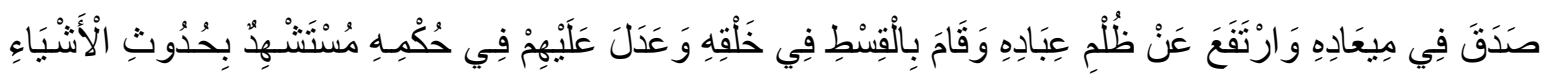

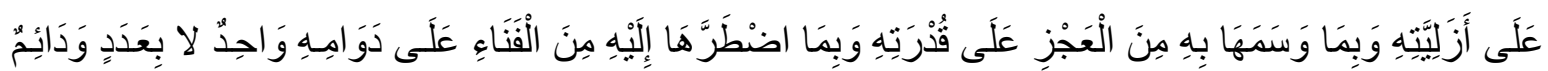

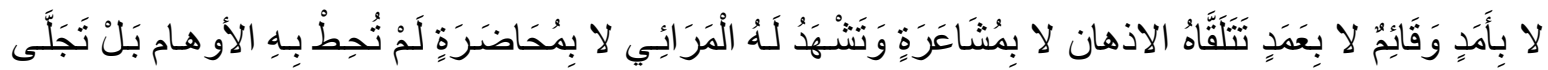

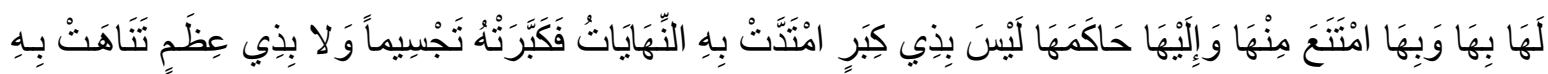

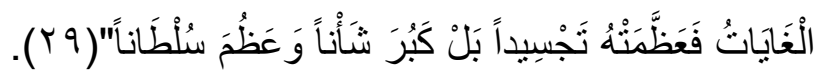

ولقد قدم الإمام جعفر الصسادق (تمى (هـ) هذا الدليل بصيغة أخرى عن طريق تساؤل قدمه أحد

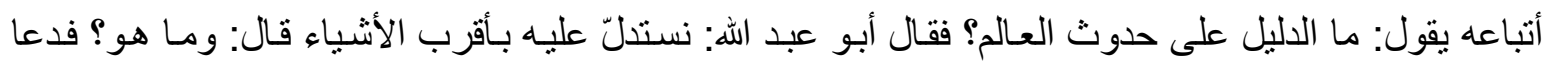
عليه السلام بييضة فوضعها على راحته فقال: هذا حصن ملموم داخله غرقئ رقيق لطيف به فضـة سائلة

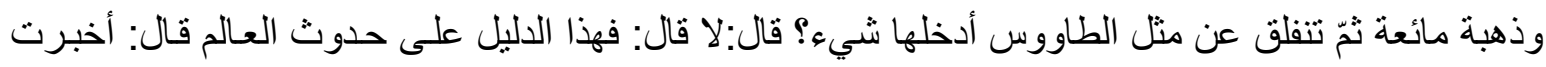

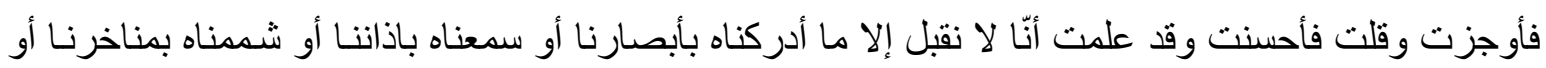

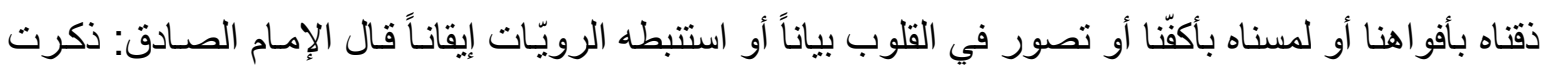

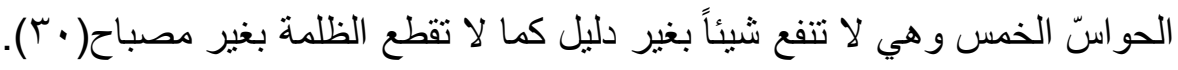
ويستمر الإمام الصادق بتقديم هذا الدليل لسائل أخر بقوله: مـا الدليل على حدث الأجسام؟ فقال: إني

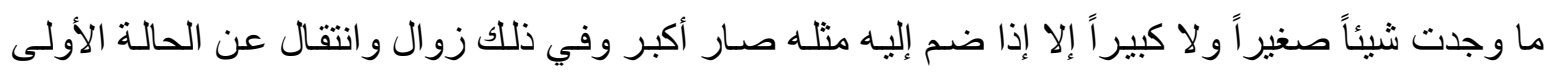

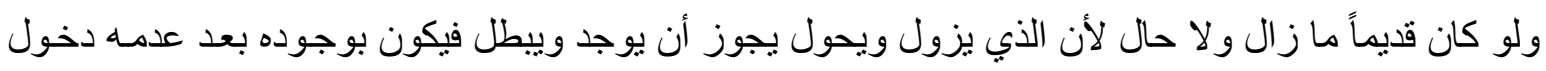

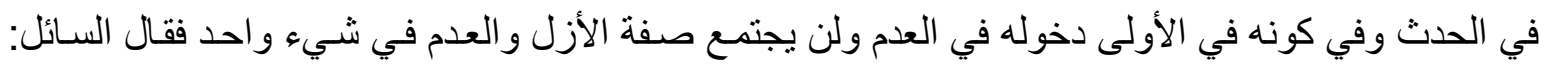

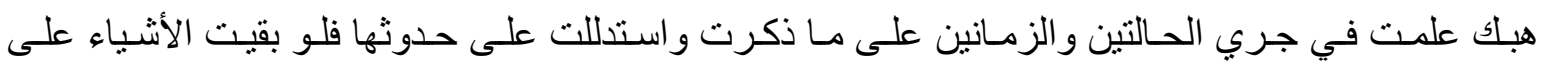

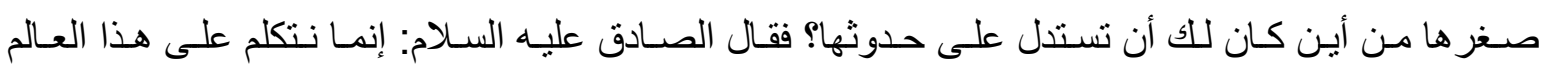

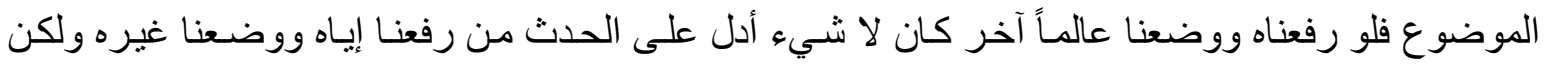

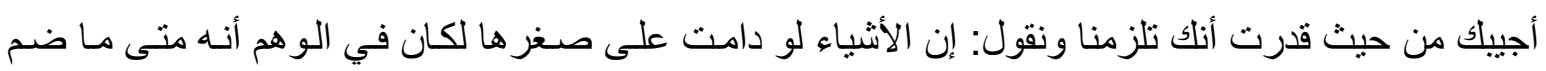

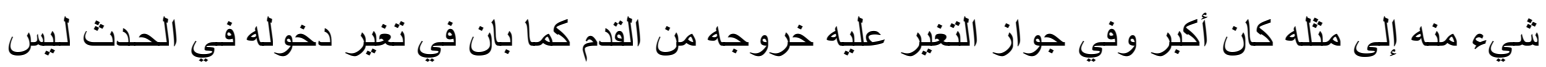

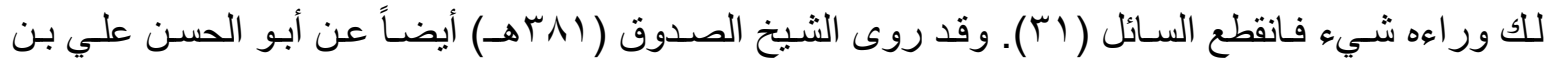

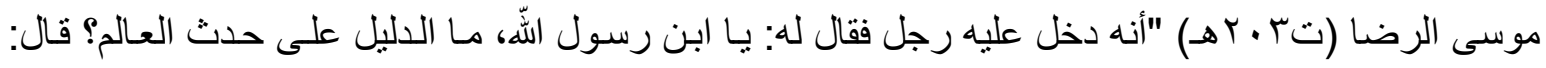

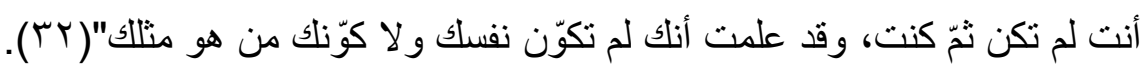

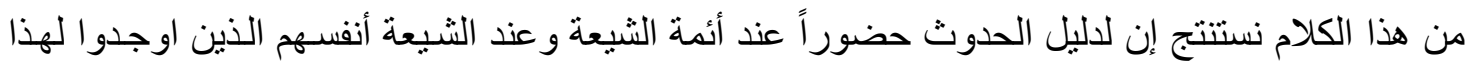

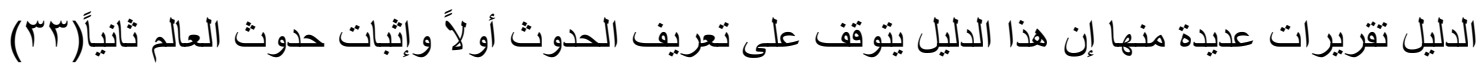
ومن جهة يقدم الثيخ المفيد هو من كبار متكلمي الثيعة هذا الدليل بصيغة منطقية فلسفية رائعة

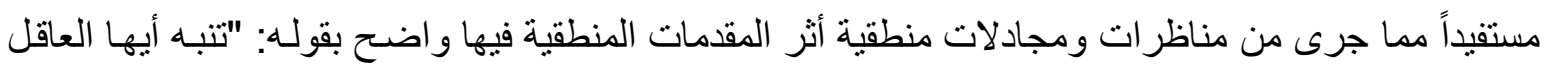


ونزل نفسك بمنزلة المسؤول و السائل فإن قيل للك أنت حادث أم قديم فالجو اب أنا حادث غير قديم وكل موجود ممكن حادث غير قديم. فإن قيل ما حد الحادث ومـا حد القديم فالجواب الحادث هو الموجود المسبوق بالعدم و القديم هو الموجود الذي لم يسبقه العدم. فإن قيل ما الدليل على أنك حسادث فالجواب سبق العدم على وجودي دليل على حدوثي. فإن قيل مـا الدليل على أن العدم سـابق على وجودك، فـالجواب الضـرورة قاضية بـأني لم أكن موجودا في زمن نوح عليه السلام فعدمي متحقق في ذلك الزمان ووجودي في هذا الزمان فعدمي سـابق

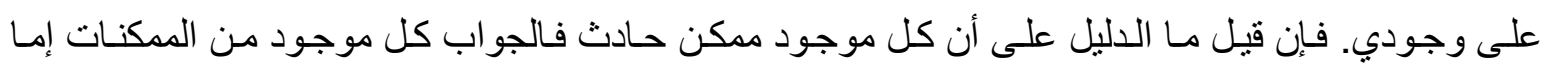

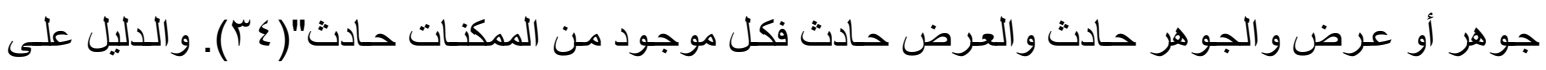
حدث العالم تغير أجزائه واحتمالها الزيادة و النقصسان و الدليل على ذلك لأنها لو كان قديما لاختص في القدم بصفة واستحال خروجه عنها لفساد تعلق العدم بالقديم والبطلان و الدليل على وجوب المحدث للعالم مـا أوجب

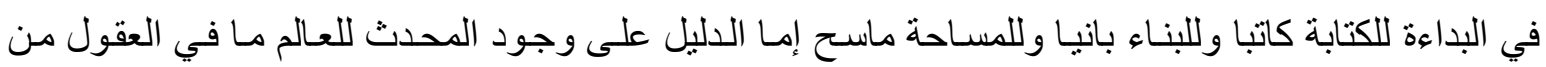

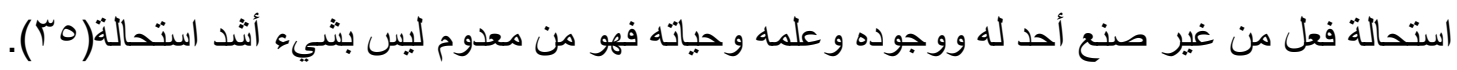
إذن الإنسـان و العـالم حادثان بـليل إن الأجسـام ومـا يجري مجر اهـا حادثة و الذي يـدل على حدوثها استحالة خلو ها من المعاني المتجددة وما لم يخل من التجدد يجب إن يكون محدثا فإذا ثبت حدوثها فلتقس على لهى أفعالنا يعلم إن لها محدثا منها العالم محدث كائن بعد إن لم يكن لان جميعه فيه أثر الصنعة من طول وقصر

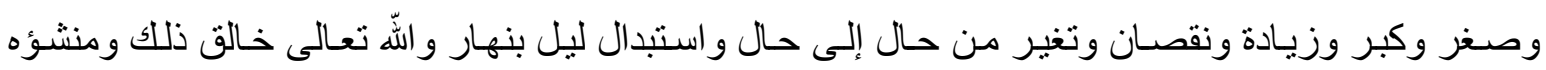

و مصوره ومبدؤه لان الصنع لا بد لله من صانع و الكتاب لا بد له من كاتب و البناء لا بد لله من بان(بَ). إمـا نصبر الدين الطوسي (ت TVY Tــ وهو مـن الذين جعلو العلم الكلام بعداً منهجياً فلسفياً ففي معرض تقريره لهذا الدليل بقول: لا يمكن الوصول إلى معرفة اللّ إلا بـالنظر في حدوث مـا لا يدخل تحت مقدور المخلوقين وهو الأجسام والإعراض المخصوصة كالألوان والطعوم والأر اييح والقدرة والحياة والثـهوة

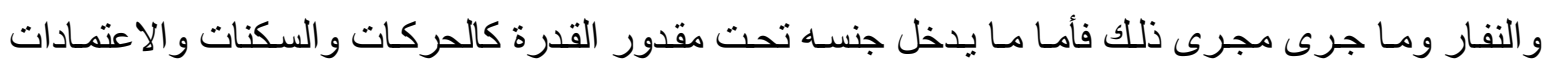
والأصـوات فلا يمكن بالنظر فيها الوصـول إلى معرفة اللّه والكلام في حدوث الأجسام اظهر لأنها معلومـة ضرورة لا يحتاج في العلم بوجودهـا إلى الدليل بل إنما يحتاج إلى الكلام في حدوثها ثم بيان إن لها محدثا يخالفها فيكون ذلك علما بالّّ ثم الكلام في صفته وللطوسي استدلالان في إثبات الحدوث للأجسام احدهما: إن ندل على أنها ليست قديمة فيعلم حينئذ أنها محدثة لأنه لا واسطة بين القدم و الحدوث و الطريق الثاني: إن نبين إنها لم تسبق المعاني المحدثة فيعلم إن حكمها في الحدوث(بV). في حين بدلو العلامة الحلي بدلوه في هذا الدليل ولكن بلغـة منطقية صسارمة فيقول: "إن العالم محدث وكل محدث؛ فله محدث أمّا الصغرى فقد تقدمث؛ وأمّا الكبرى فلان كل محدث ممكن وكل ممكن فله مؤثّر أمّا الصغرى فلان المحدث قد اتصفت ذاته بصفتي الوجود و العدم فهي قابلة لهما بالضرورة و لا نعنى بـالمكن إلا هذا وأمّا الكبرى فضرورية وقد تقدمت إذا ثبت هذا فنقول المؤثر إن كان ممكنا افتقر إلى مؤثر أخر فإمّا إن

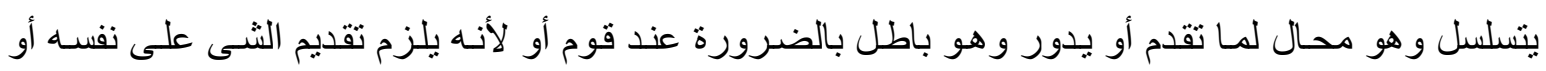
ينتهي إلى الواجب لذاته وهو المطلوب فان قيل المعدوم نفى محض فلا يصـح الحكم عليه بالقبول سلمنا لكن 
يجوز إن يكون الماهية واجبة العدم حين العدم وواجبه الوجود حين الوجود فلا يلزم الإمكان كمـا إن المحدث بشرط الحدوث لا يجوز في العقل فرض تقدمه لا إلى أول و إلا لزم صحة كون الحادث بشرط الحدوث أزليا هذا خلف فلصحة وجوده بذاته"( (؟).

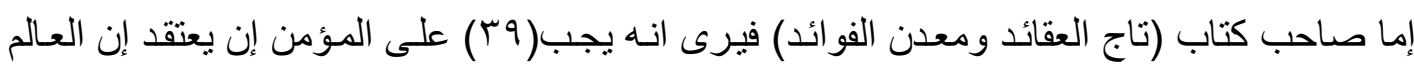
محدث كائن بعد إن لم يكن ودليل الافتقار فيه يدلنا على احتياجه والمحتاج في وجوده إلى غيره يتعلق بالدليل على حدثه وذللك إنـا شـاهدناه تارة يجتمع وتـارة يفترق وكونه لا يبقى على حالة واحدة بل توجد فاسدة بعد الكون وقد كانت بعد الفساد فهي بهذه الأحوال تدل على حدثها وذلك إن علته غير عينه كما نرى عيانـا إن علـة حركة الطاحونة غير الطاحونة وعلة حركة أثخاص الحيوان غير أثخاصسه إذ لو كانت ذو اتها علة لحركتها لكانت أبدا توجد متحركة لوجود ذو اتها وكأنها حينئذ لم تكن علة بل كانت عين الثيء ولمّا كنّا نر اها باقية بعد ذهاب الحركة لا تتحرك صحّ إن علة وجود الأشياء غير ذو اتها فلمّا بـان لنا ذلك وتحققتاه صـحّ لنا إن العـالم بما يحويه ذاتا واحدة من حيث الجسمية وشيئا واحدا وكان البعض منه متحركا والبعض ساكنا وثبت إن حركة المتحرك وسكون الساكن ليس من قبل ذاته إذ لو كان من قبل ذاته لكانت الأبعاض كلها متحركة أو سـاكنة إذ إن الذات واحدة وإذا ثبـت إن حركـة المتحرك وسكون السـاكن ليس من قبـل ذاتـه وجب إن يكون المحرك المسكن هو المحدث فالعـالم إذا محدث ولمّـا كان العالم بكليته جسما ذا أجزاء و ابعاض معدودة متغايرة في الإشكال و الصور مثلمـا نعاين إن صور الأفلاك و الكو اكب التي هي ابعاض العالم غير صور النـار وشكلها

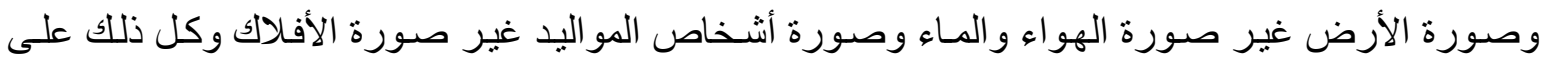
تباين صـوره مفنّدة والبعض بـالبعض متصـل فدلّ إن العالم لم يجتمع إلا بفعل فاعل و العـالم مصنوع محدث و المحدث يقضضي الصانع المحدث( • ع). ولمّا ثبت حدوث العالم" وجب احتياجها إلى صـانع ضرورة احتيـاج كلّ صنعة إلى صانع وهو المطلوب. و إذا ثبت أنّ للعالم صـانعا فلا يجوز أن يكون محدثا مثله لأنّهـه لو كان محدثا افتقر إلى محدث آخر بالضّرورة فإن كان هو الأوّل لزم الدّور وإن كان محدثاً ثنانياً أو ثالثاً أو رابعاً إلى لى

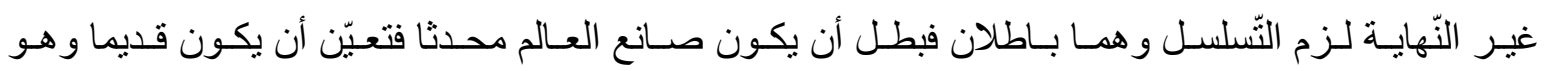

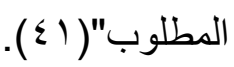

\section{ب. الفطــرة:}

يعتبر هذا الدليل من الأدلة الذاتية المباشرة التي لا تحتاج إلى إتباع طرق(لميـة أو انيـة)(بـ ) لإثبات

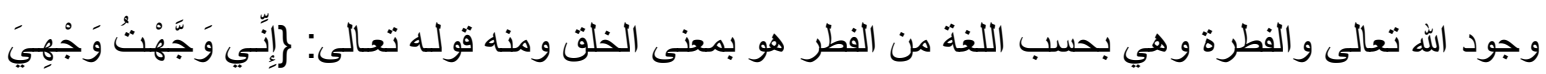

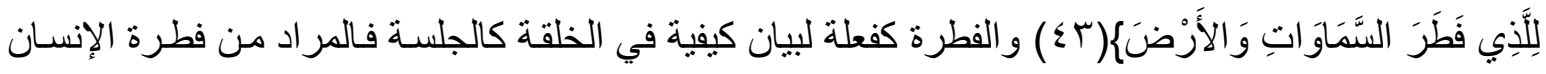
هي كيفية في خلقة الإنسان وهي ترجع إلى كيفية في هويته التي منها إدر اكه بالعقل البديهي وهذا هو الذي عبر عنه في المنطق بالفطريات أي القضـايا التي قياسـاتها معها كقولهم: الاثنين خمس العشرة وكعلم النفس بالنفس فلا يحتاج إلى وساطة شكل قياسي كما لا يخفى ولذا يعدّ من أقسام العلم الحضوري فالإنسـان بفطرتـه يعلم بنفسه ويحب الكمال و الجمـال وسمي هذا الإدر الك بفطرة القلب ثم بعد وضوح معنى الفطرة فليعلم أن المستـل بـالفطرة على إثبـات وجـود الله وصـفاته وتوحيده أراد الفطـرة القلبيـة وقـال: إن القلب يعلـم بـالعلم الحضوري ربّه ويعرفه و الدليل عليه هو رجاؤه بالقادر المطلق عند تقطع الأسباب الظاهريـة المحدودة وحبـه 
له و إن غفل عنه كثثر من الناس بسبب الاشتغال بالدنيا في الأحوال العادية إذ الرجاء والحب فرع معرفته بـه

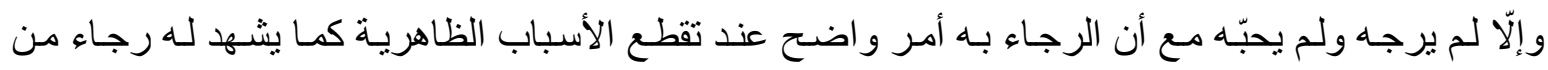
كسرت سفيتته في موضـع من البحر لا يكون أحد ولا إمداد بقدرة ور اء الأمور العادية ومـع أن حب الكمال المطلق لا خفاء فيه حيث إذا نرى أنفسنا عند عدم إثباع كمسال من الكمالات غير آيسين من النيل إلى كمـال فوقه إلى أن ينتهى إلى كمال لا نهاية لـه وهو الذي يوجب السكون و الاطمئنان و لا نشبع من حبه ولا نشمئز

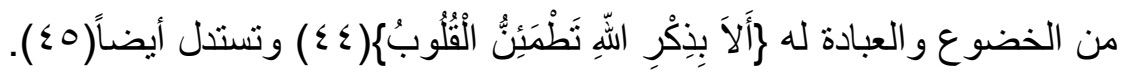

ويرى الثيعة عموماً إن الإيمان الفطري بوجود اللّ يشمل جميع الكائنات وأن "وجود الصـانع فطري

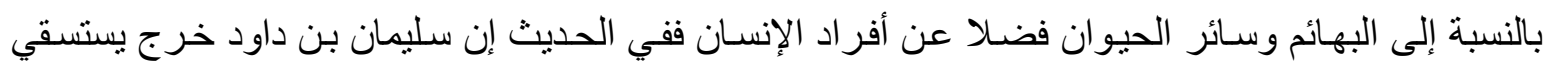

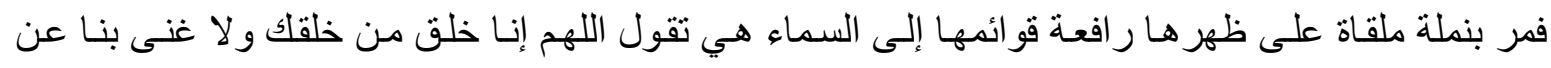

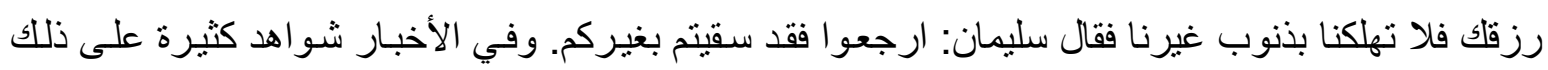
يقف عليها المتتبع. وحكي الفخر الرازي عن رجل أنه اتفق في بعض الأزمنة جدب وقحط شديد فخرج الناس إلى الصحر اء للاستسقاء ودعوا فلم يستجيب لهم قال الرجل فصعدت إلى الجبال فرأيت ظبيا يسرع إلى المـاء من شدة العطش فلما انتهى إلى الغدير رآه جافا من الماء فتحير وجعل يكرر النظر إلى السماء ويحرك رأسـه مر ارا فظهرت سحابة وارتفعت وأمطرت حتى امتلأ ذلك الغدير فترب الظبي ورجع"( ؛ ؟ ) وقد أكد هذا الدليل القران الكريم الذي يعتبر وجودَ اللَّ أمراً واضحاً وغنيّاً عن البرهنة ويـرى أنّ أنّ

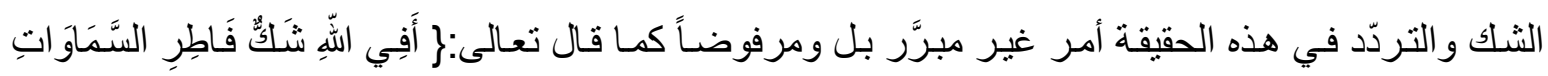

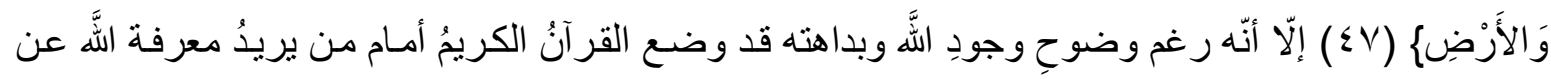

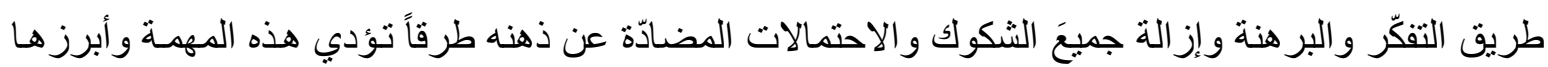

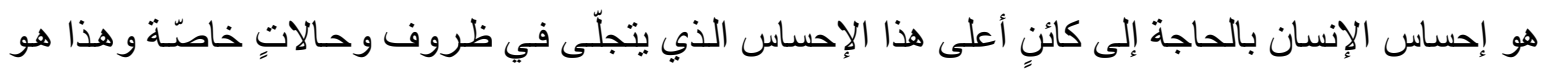

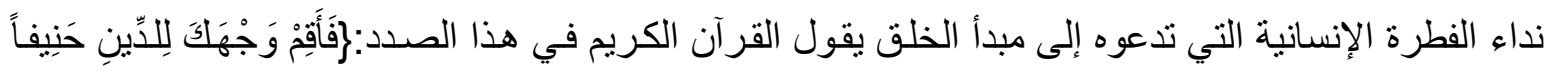

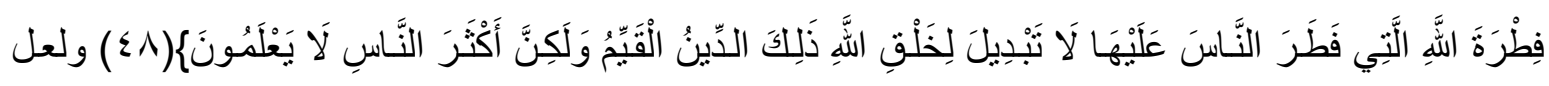

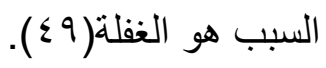

وبالإمكان تقوية الفطرة الموجودة في الإنسـان وذلك من خلال تكامل "النفس وتركيز التفات القلب

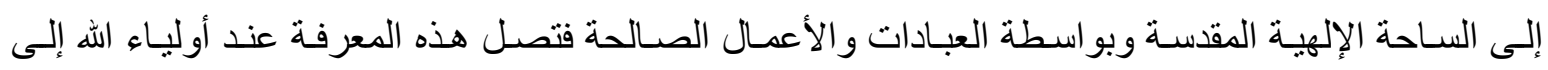
درجة من الوضوح بحيث يرون الله أظهر من كل شيء كما جاء في دعاء عرفة: أيكون لغيرك من الظهور مـا ليس للك حتى يكون هو المظهر للك" ( •).

م.الر ستـــــ ول والَ]:

بعيداً عن كل الاستدلالات المنطقية والعقلية التي أولاها الثيعة عنايـة خاصـة لإثبات وجود اله تعالى

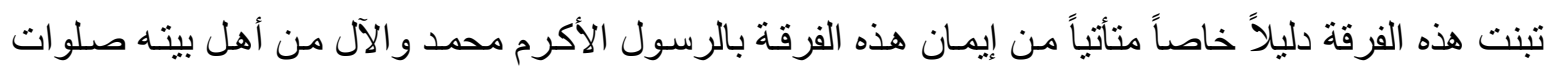

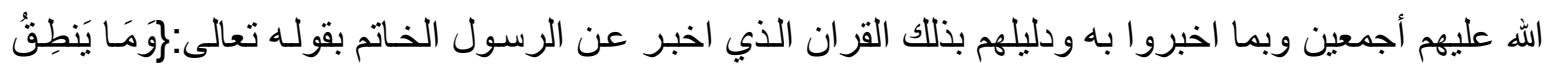

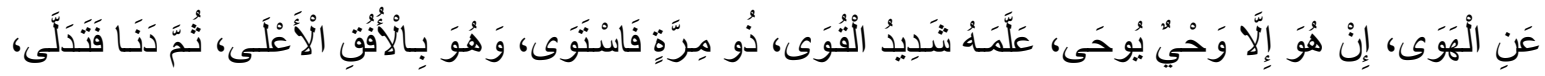




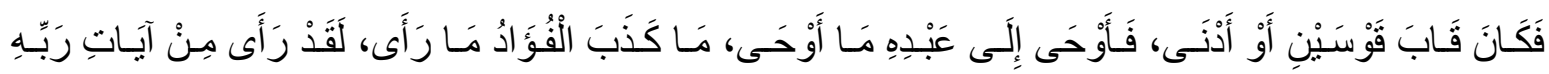

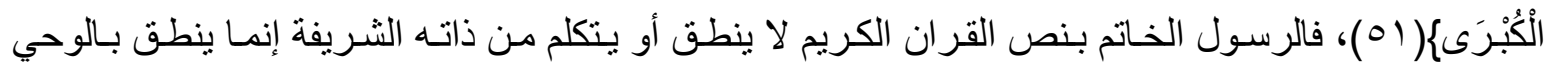

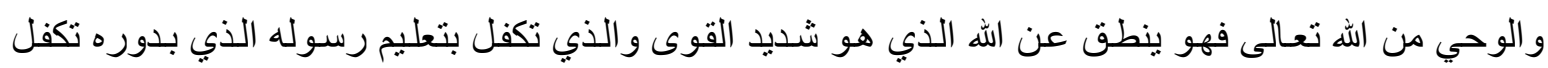

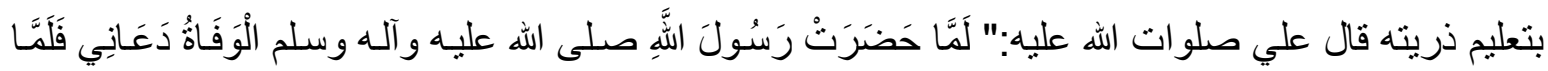

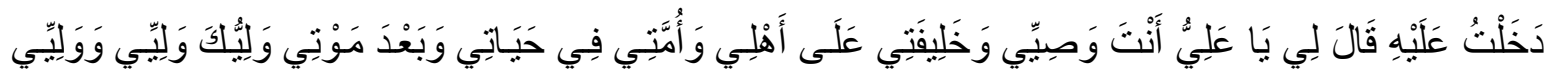

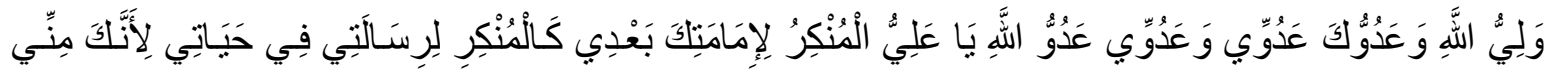

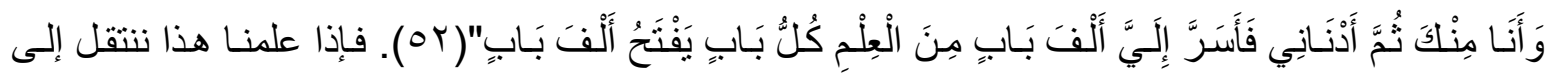

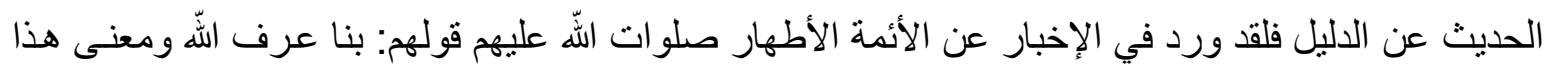

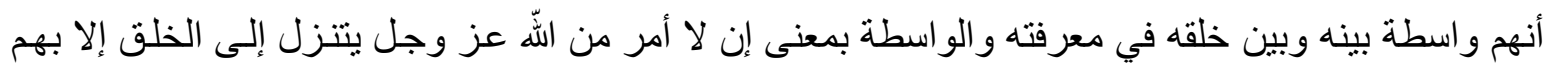

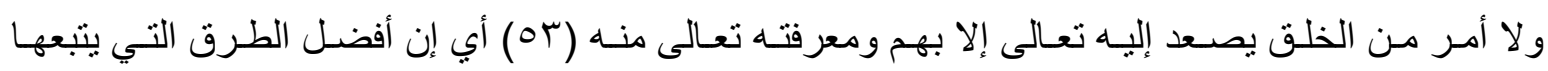
الإنسان لمعرفة الله تعالى هي الطرق التي تمر عبر الرسول الأكرم والأئدة الأطهار من ذريته لان مسلكهم الأنه

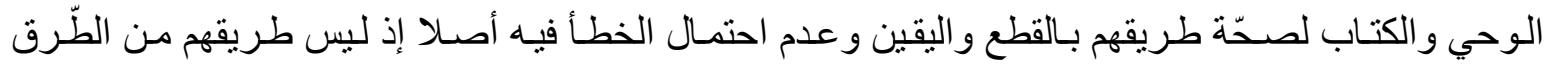

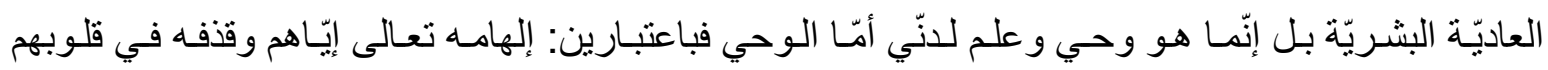

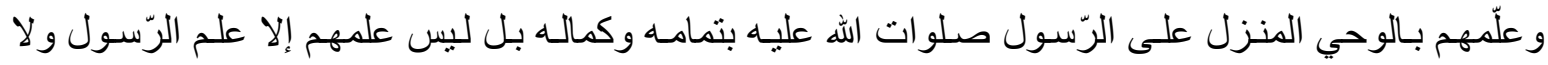

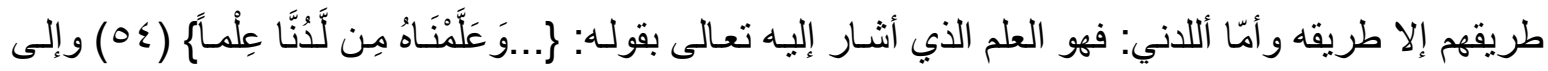

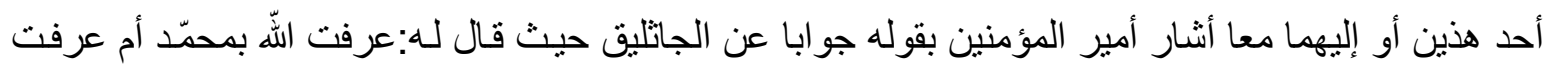

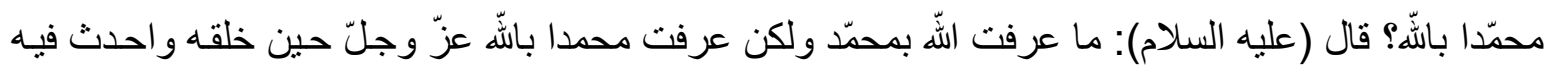

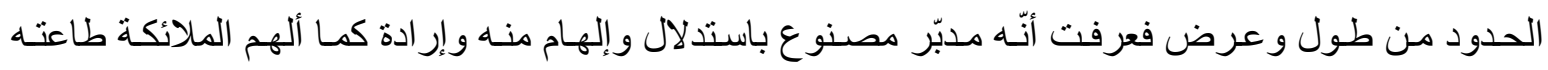

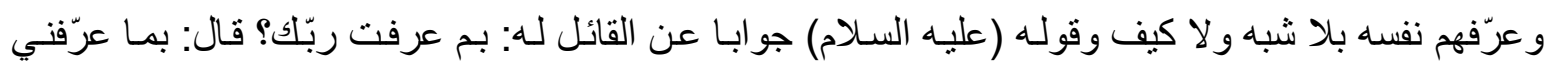
نفسام(00). (20)

وقد ذكر صاحب كتاب( مفاتيح الجنان) بسند معتبر" أن الثيخ أبا عمرو النائب الأول من نواب إمام

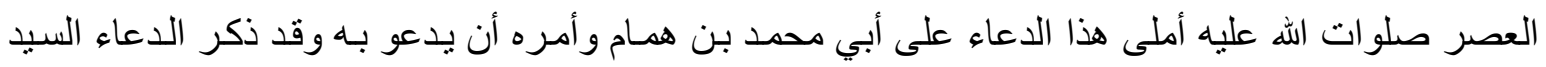

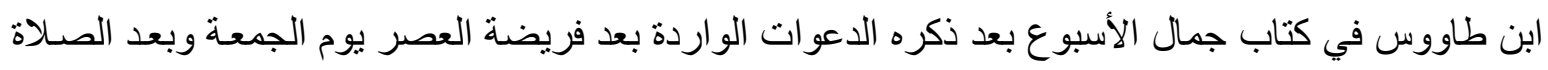
الكبيرة وقال: وإذا كان للك عذر عن كل ما ذكرناه فاحذر أن تهمل هذا الدعاء فإنا قد عرفناه من فضل التهل اله جل

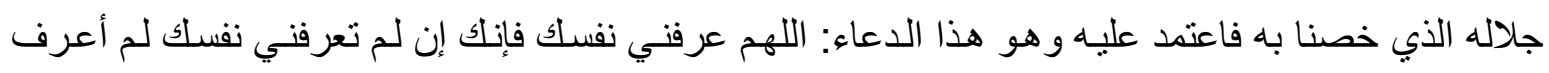
رسولك. اللهم عرفني رسولك فإنك إن لم تعرفني رسولك لم أعرف حجتك. اللهم عرفني حجتك فإنك إن لم تعرفني حجتلك ضللت عن ديني"( (07)، إذن للناس طريقان صحيحان للمعرفة: الأول: من اله أي بالله نعرف فالإنسان إذا لم يعرف الله لاستطيع إن يعرف الرسول المخبر عن الله ولا الأئمة الذين هم كالرسل والأنبياء

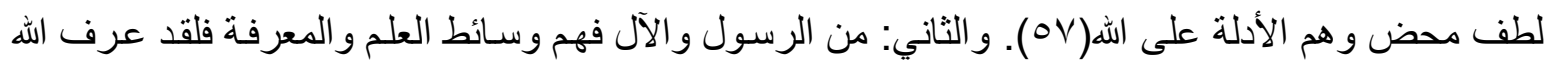

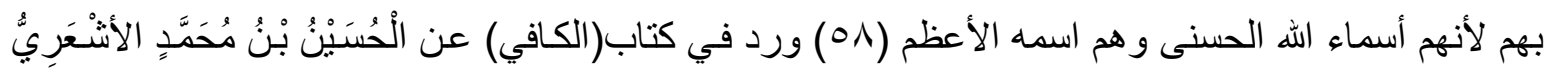

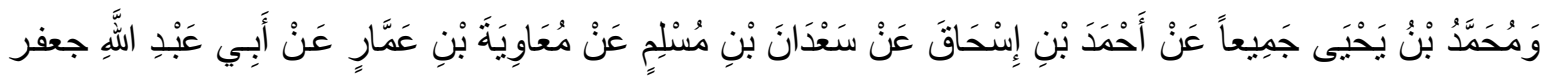




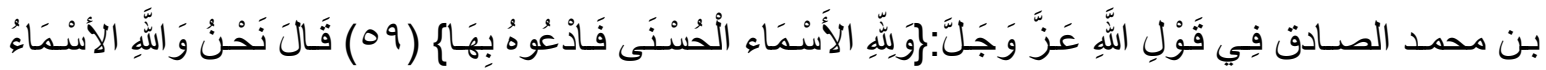

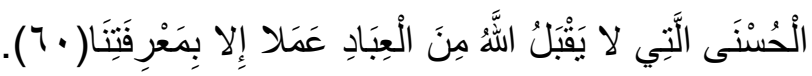
ونقل صاحب كتاب (الميزان في تفسير القران) عن الإمام الصادق "فيه اخذ الاسم بمعنى مـا دل على

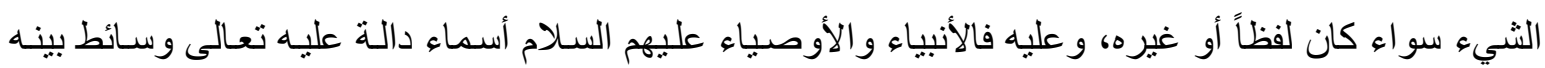
وبين خلقه، لأنهم في العبودية بحيث لبس لهم إلا الله سبحانه فهم المظهرون لأسمائه وصفاته"( (آ). وورد

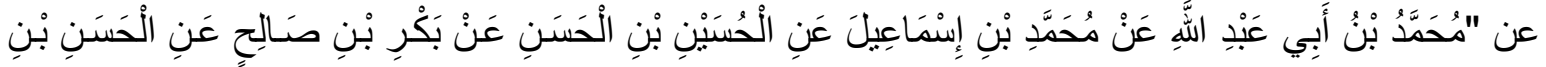

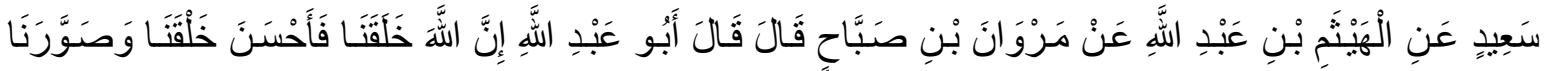

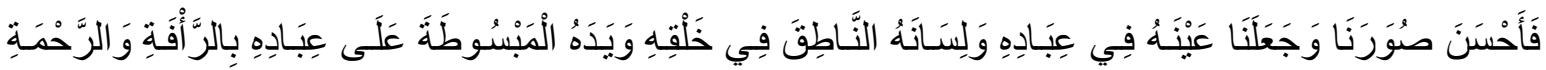

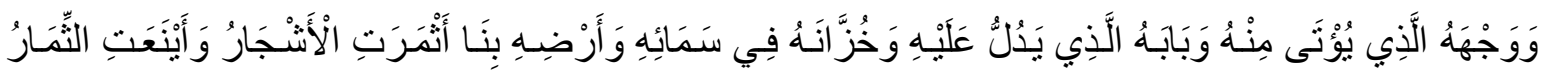

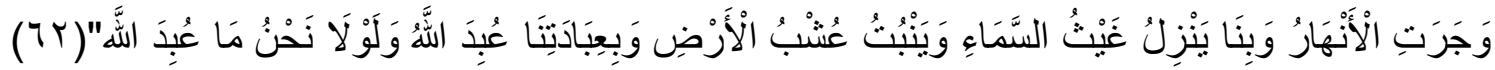

ثانيا: المعترزلـــة: 1. بـث في نشأة المصطلح (1"1).

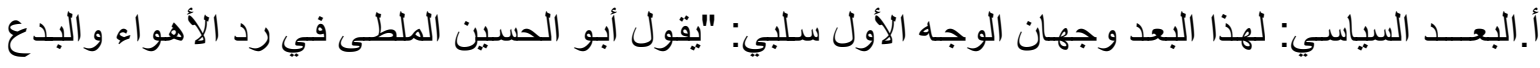

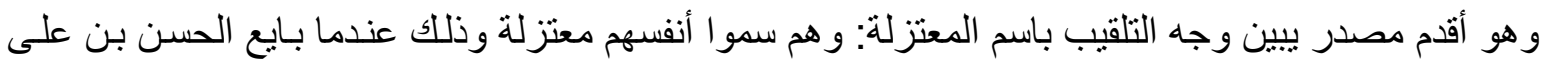
عليه السلام معاوية وسلم إليه الأمر اعتزلوا الحسن ومعاوية وجميع الناس وكانوا من أصحاب علي ولزئ وهابعا

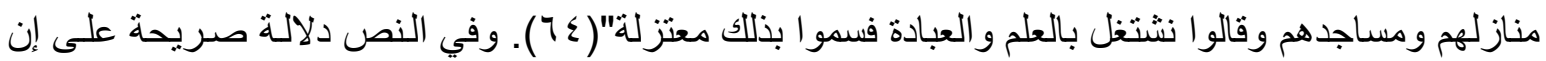
المتنزلة نفر من الناس خافوا الفتنة السياسية فامسكو ا على عقائدهم وحبسوا أنفسهم في مساجدهم ومناز لهم

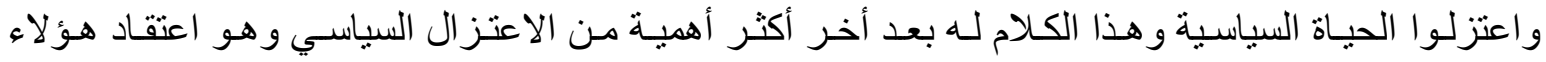

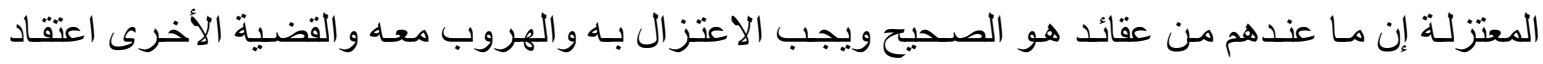
هؤلاء المعتزلة عدم شر عية كل من الإمام الحسن بن علي (ت .0هـ) ومعاوية بن أبي سفيان (ت . بهـ).

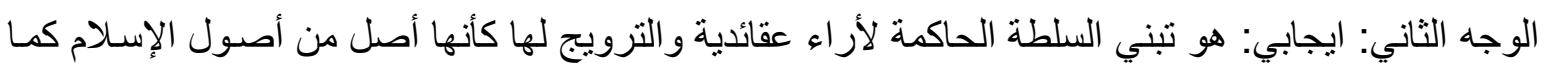

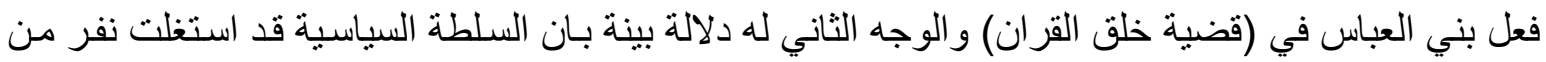

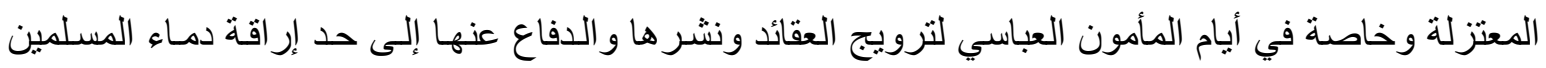

$$
\text { و إباحة أمو الهم و أعر اضهم. }
$$

ب.البعـد العقائدي: في هذا البعد نريد إن نبين قضية في نظرنا جوهرية ومهمة وان الوقوف عليها وتحليلها سوف يساهم بحل جانب مهم من جوانب نثـأة المصطلح (الاعتز ال) وما سـاهم بـه في التأثير على عقائد

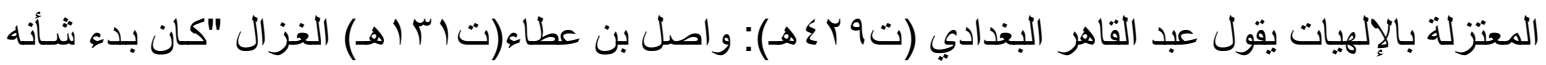

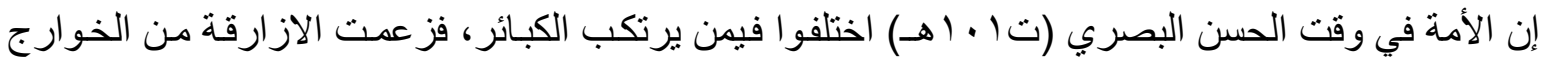

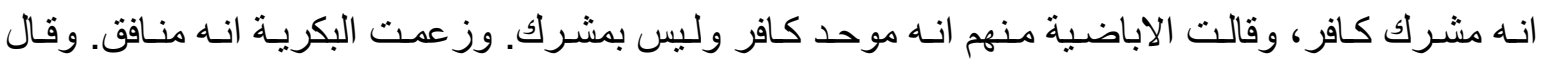
الجمهور الأعظم من الصحابة والتابعين انه مؤمن بتوحيده ومعرفته بربه، وتصديقه لكتب ربهـ ورسوله،

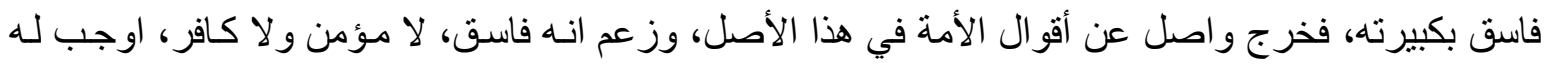


الخلود في النار مع خروجه من الكفر، فلمـا رأى الحسن خـلاف واصل على الأمسة، طرده عن مجلسـه. فقال الناس فيه انه اعتزل الأمة"(70). وقال فخر الدين الرازي (ت7 ـ 7هـ): "كان و اصل بن عطاء وعمرو بن عبيد من تلامذة الحسن البصري ولما أحدثا مذهبا وهو أن الفاست لبس بمؤمن و لا كافر اعتز لا حلقة الحسن البصري وجلسـا ناحيـة في المسجد. فقال النـاس: إنهما اعتز لا حلقة الحسن البصري فسموا معتزلة" (77). وقال الثيخ المفيد: "أما المعتزلة وما وسمت به من اسم الاعتز ال فهو لقب حدث لها عند القول بالمنزلة بين المنزلتين وما أحدثه و اصل بن عطاء من المذهب في ذلك ونصب من الاحتجاج لـه فتابعه عمرو بن عبيد وو افقه على التدين به من قال بها واتبعهما عليه إلى اعتز ال الحسن البصري و أصحابه و التحيز عن مجلسـه

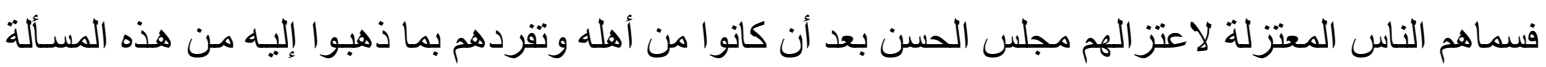

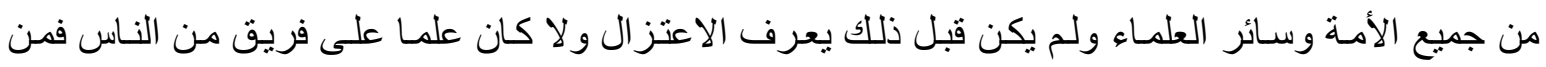

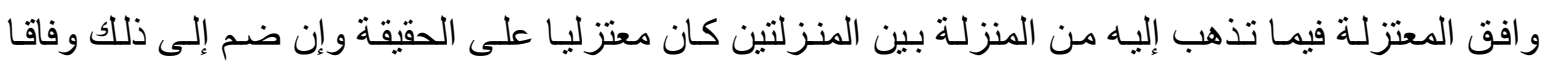
لغير هم من أهل الآر اءو غلب عليه اسم الاعتز ال ولم يخرجهه عنه دينونته بمـا لا يذهب إليه جمهور هم من المقال"(TV). و وعند تحليلينا لهذه النصوص، نخرج بنتائج عديدة منها: ا.اختلاف المسلمين وتحير هم في الحكم على القضية الواحدة مع العلم أنهم قريبو عهد بنبيهم و لا يزال الدين نقي طاهر لم يتلبس بالضلالات. r.شعور و اصل بن عطاء بالتفوق العلمي وبأنه اعلم من أستإذه (الحسن البصري) هذا مـا دفعـه إلى تجاوزه و الاعتز ال عنه مكانياً وفكرياً. r. مع (الاعتز ال = و اصل بن عطاء) فتح بـاب الاستدلال العقلي وفتح الباب على مصر اعيه إمـام المسلمين فيما يتعلق بعقائدهم ولم يغلق لحد الآن. ج.البعــــ النصي: على الرغم من تفاخر رجالات فرق المعتزلة بالعقل وباستـلالاته إلا إن هنـاك بعداً نصياً

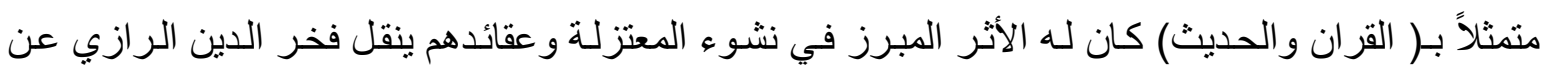

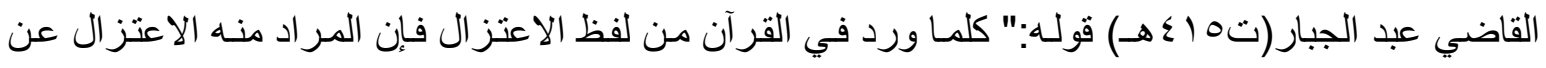

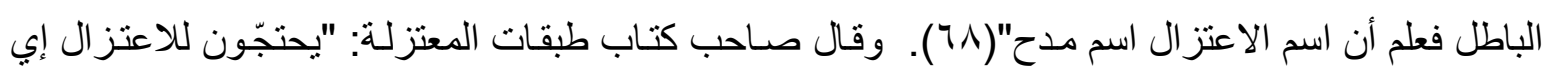

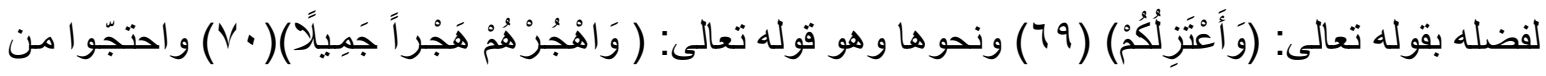

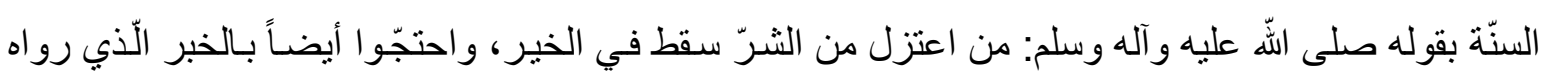
سفيان الثوري عن ابن الزبير عن جابر بن عبد اللّه عن النبي صلى اللّ عليه وآله وسلم وهو قوله صله صلى اللّه عليه و آله وسلم: ستفترق أمّتي على بضع وسبعين فرقة ابرّها واتقاها الفئة المعتزلـة، وهو تمـام الخبر، ثم قـال

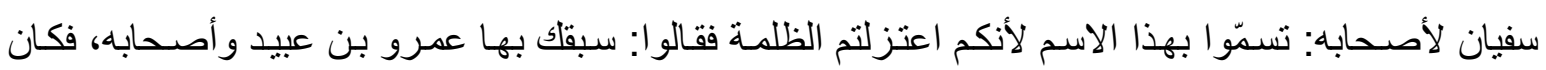
سفيان بعد ذلك يروى: واحدة ناجية"(V).

ب. أدلة وجود الله عندميم:

على الرغم من إن جل كتب المعتزلة الأوائل لم تصل(م/VY) وقد ضـاع أكثرهـا(V) ولكن المتوفر منها يغني الباحث في الوقوف على أر ائهم وخاصـة فيمـا يتعلق بموقفه من الإلوهيـة والأدلة التـي قدمت في 
إثباتها وقبل التطرق إلى هذه النصوص بالتفصيل حري بنا إن ننوه إلى إن اغلب الباحثين و الدارسين لتراث المعتزلة غالباً ما يلجئون إلى التعميم و عدم الفصل عندما يتحدثوا عن أراء هذه (الفرقة = فرق) أنهم يتكلمون

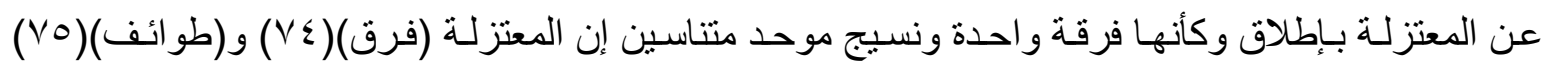
و(مدارس)(VT) و(طبقات)(VV) لكن هذا لا يعني انه لا نوجد بعض المشتركات وخاصـة في (جليل الكلام) و التي يتفق عليها اغلب فرق المعتزلة التي وجدت في النص ألقراني القاعدة الصلبة التي ينطلقو امنها لتدليل

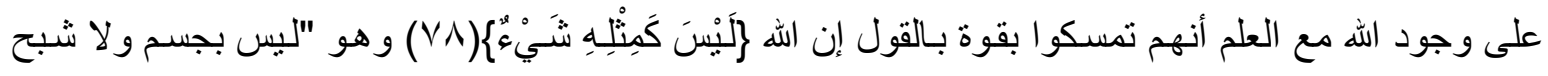

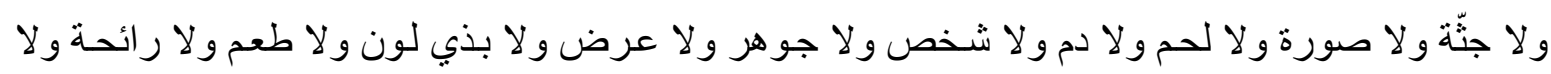

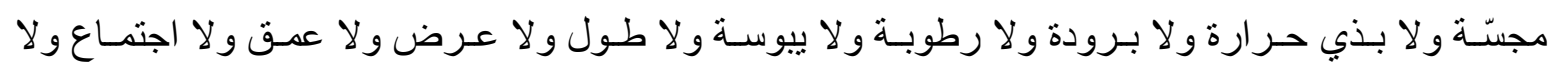

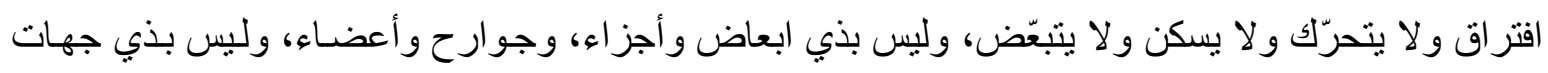
و لا بذي يمين وشمال و إمام وخلف وفوق وتحت، ولا يحيط به مكان، ولا يجرى عليه زمـان، ولا تجوز عليه

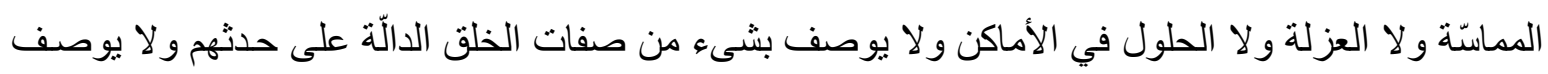

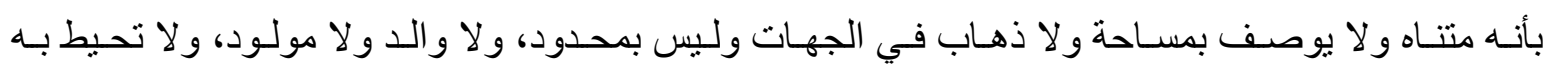

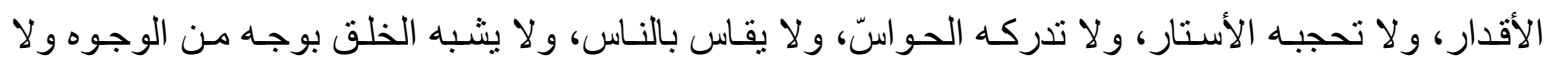

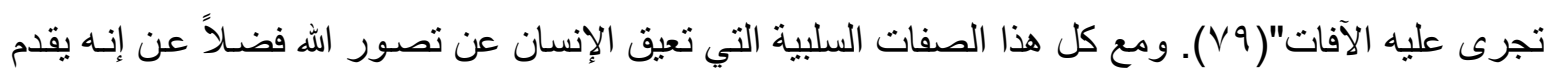

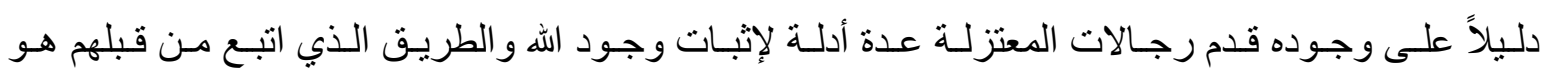
(الاستدلال العقلي) يقول القاضـي عبد الجبار :"يصل الإنسـان بالعقل إلى إدرالك وجود اللّ"(• •) ويقول عبد

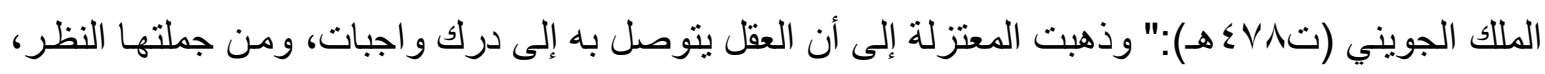

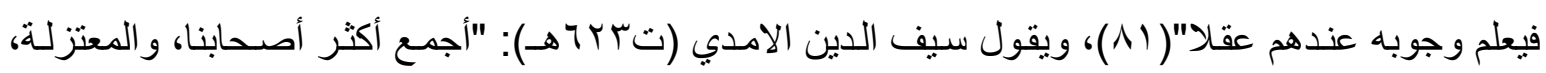
وكثير من أهل الحق من المسلمين، على أن النظر المؤدى إلى معرفة الله ـ تعالى - واجب. غير أن مدرك

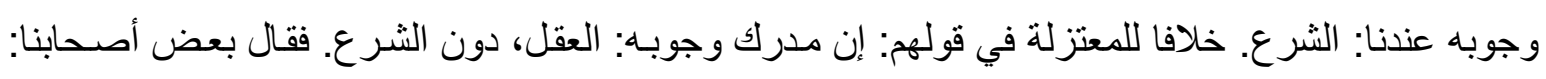
أول واجب على المكلف معرفة الله - تعالى - إذ هي أصل المعارف الدينية، والواجبات الثرعية. وقال غيره:

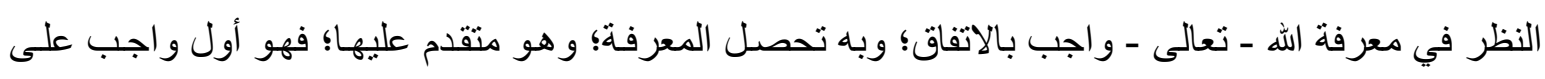

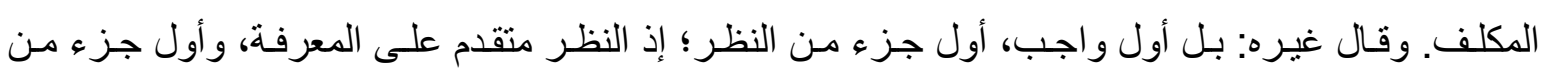

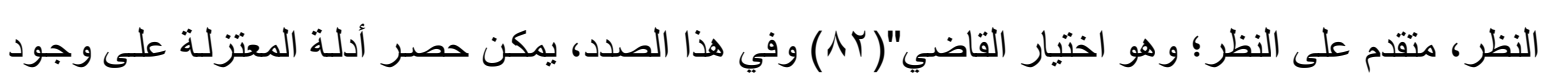

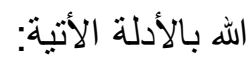

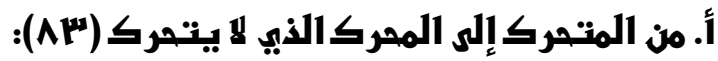

هو من الأدلة التي يشترك بها بعض المتكلمين من معتزلة البصرة مـع الفلاسفة و الدليل قديم وذو حضور في الفلسفة يعد أرسطو طاليس أول من قال به (ع) فقد ورد في كتابه (الكون و الفسـاد) إن" المحرك الأول غير المتحرك هو المبدأ الوحيد للحركة العالمية" (10) و المحرك الأول في فلسفة أرسطو هو" الله ، و هو يحرك العالم ، و لا يتحرك معه، وهو فعل محض لا يعتريسه التغير، و المحرك و المتحرك متضـايفان، لأن احدهما لا يفهم إلا بالقياس إلى الآخر. المحرك هو الذي يعطي الحركة، والمتحرك هو الذي يقبلها، وكل

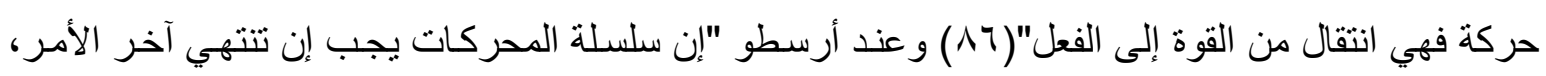


إلى محركين أولين: ا. محرك أول يتحرك، هو السماء الأولى أو الفلك المحيط. و r. ومحرك أول لا يتحرك هو اله"(^V). وقال أرسطو "انه لا بـد إن يكون للحركة مصدر إذا أردنا إن لا نغطس في رجوع لا نهائي،

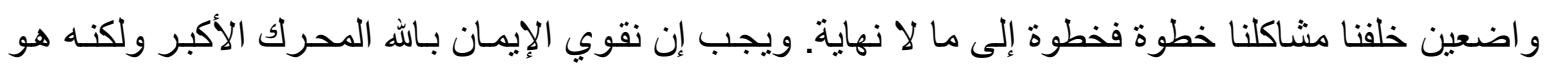

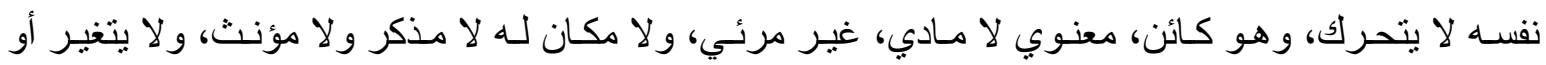
يتأثر ، تام وأبدي. إن اله لا يخلق العالم، بل يحركه، و لا يحرك العالم كقوة ميكانيكية ولكن كمحرك كلي لجميع عمليات العـالم. إن الله يحرك العـالم كمـا يحرك المحبوب المحب. انـه السبب النهائي للطبيعـة. و القوة الدافعـة للأشياء وهدفها، انه صورة العالم، ومبدأ حياته. ومجموع تفاعله الحيوي وقوته، وهدف نموه الغريزي"(^^). ويرى أبو الهذيل العلاف (تهـr هــ) إن الحركة هي انتقال الجسم من المكان الأول للمكان الثاني ويعرف السكون بأنه لبث الجسم في المكان زمانين متتاليين وتعريف العلاف هذا بـأن الحركة هي السكون في

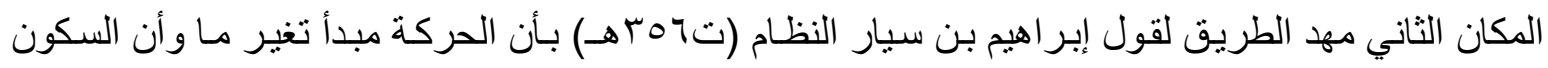

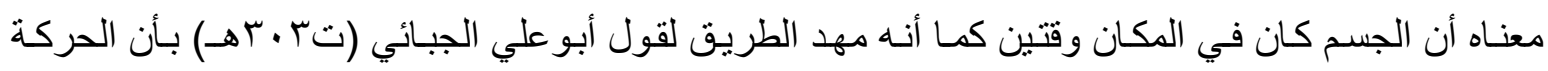
و السكون أكوان وأن معنى الحركة حسب رأي الجبائي هو معنى الزوال فلا حركة إلا وهي زوال وأنه ليس معنى الحركة معنى الانتقال ولقد اعتبر كل من أبو الهذيل والنظام والجبائي الحركة كونـا في المكان الثاني ويقول معمر بن عباد (ت 10 Pه): إن السكون هو الكون الحركة إذن في رأي المعتزلة كون بمعنى أرسطو

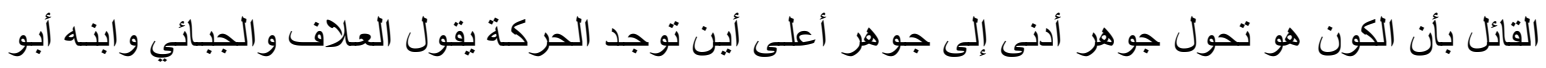
هاثم الجبائي(ت اسMهـ) إن الحركة تحصل في الجسم وهو في المكان الثاني لأنها أول كون في المكان الثاني ويضيف أبو الهذيل العلاف قائلا: إنه لا بد للحركة من مكانين وزمانين ولابد للسكون من زمانين كيف تحل الحركة في الجسم ويقول العلاف: حركة الجسم جائزة بحركة تحل في بعض أجز ائه ويقول الجبائي: الجسم

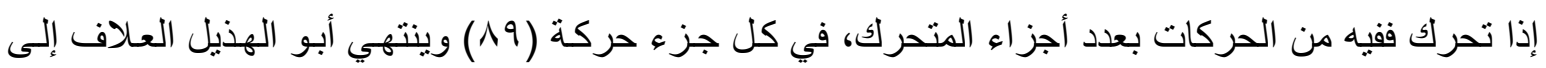
تقرير هذا الدليل إلى القول:" لكل حركة محرك، وهكذا، ولا يمكننا التسلسل في مجموعة العلل إذن، هناك محرك أول لا يتحرك بآخر وهو اللّ"( • 9).

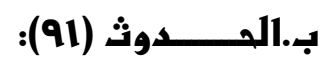

يرى بعض الباحثين ان أول (r9) من حرر ولخص هذا الدليل هو" أبو الهذيل وتابعـه عليها من بعده

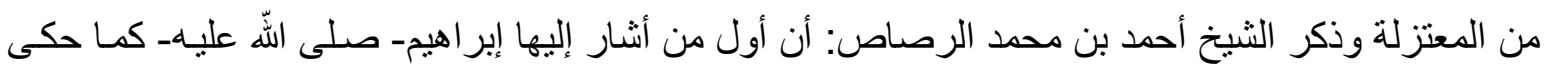
اللّّ عنه في آيـة الأفول، وهو (أن هذه الأجسـام) على تنو عها مـن حيوان وجمـاد، ونـام وغير نـام (محدثـة) و المحدث: هو الموجود الذي لوجوده أول (والمحدث لا بد لـه من محدث) وقالت الدهريـة: بل هي قديمة لم يسبق وجودها عدم، ولا يخالفون في تر اكيبها كالحو ادث اليومية أنها محدثة (و الذي يدل على) إبطال مذهبهر (أن هذه الأجسام محدثة أنها لم تخل من الأعر اض المحدثة) ولم تتقدمها، ومـا لم يخل من المحدث ولم يتقدمها فهو محدث مثله، و هذه الدلالة مبنية على أربع دعاوى وهي: أن في الجسم أعر اضـا غيره، و أنها محدثة، وأن

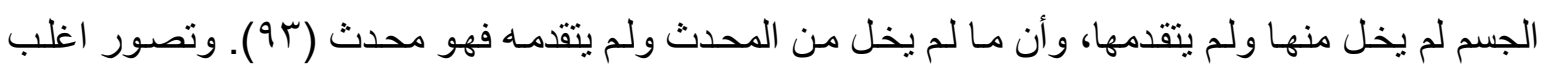
المعتزلة لهذا الدليل مبني على التقرير الأتي: العالم كان معدوما واستمد وجوده من اللّه تعالى و العدم مـادة العالم و الوجود صورة العالم والمادة لا تتحقق بدون صورة فالعدم لا يتحقق بدون وجود و الوجود من الّّه فقط 
خلاصة فكرة المعتزلة هنـا إن تأثير القدرة أي قدرة اللّه في الوجود فقط والقادر يعطي الوجود و الممكن في

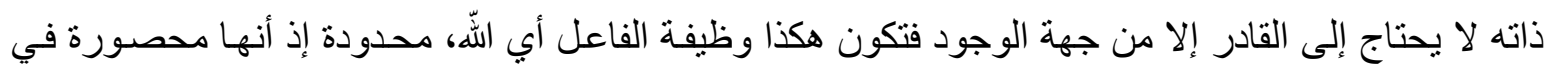
منح الوجود فقط للمعدومات الممكنـة لأنـه لـو منح أيضـاً ماهيـة المعدوم لأصبحت ماهيتـه تعـالى في نظـر

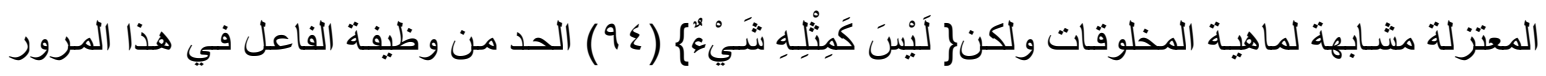
الصفات الذاتية للجواهر و الأعر اض لها ذو اتها التي لا تتعلق بفعل الفاعل وقدرة القادر إذا أمكن أن نتصور الجوهر جو هر ا وعينا وذاتا فعلى ذلك تكون وظيفة اللّ في خلق العالم محصورة في منح الوجود فقط للمعدوم وليس في خلق الماهيات المعدومات(90).

إذن كل محدث يحدث عن علة و لا يمكن التسلسل إذن هناك علة أولى غير محدثة وهي اللّ وبهذا

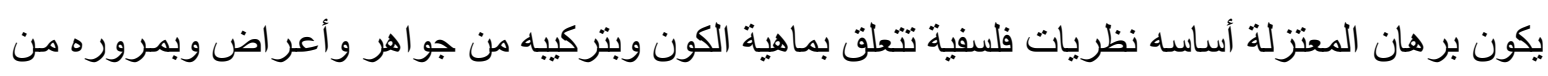

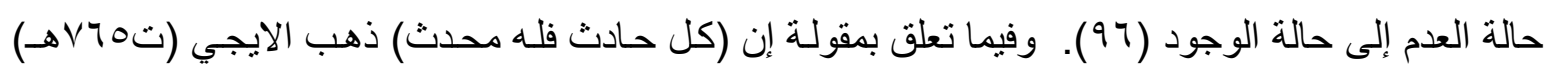
إلى إن أكثر مشايخ المعتزلة ذهبت إلى القول أن هذه المقدمة استدلالية واستدلوا عليها تارة بأن أفعالنا محدثنة

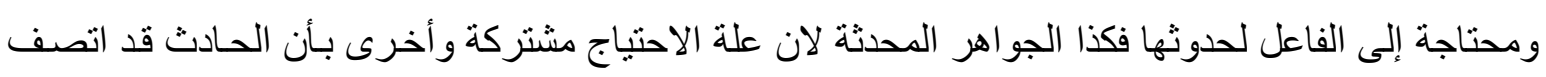

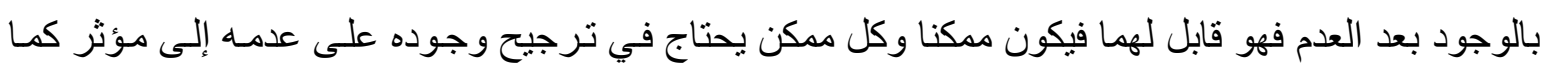

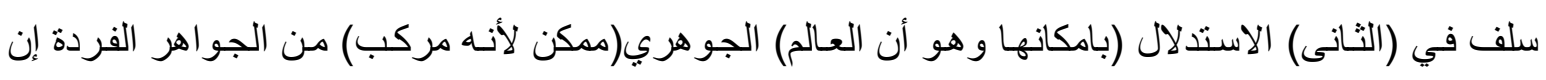

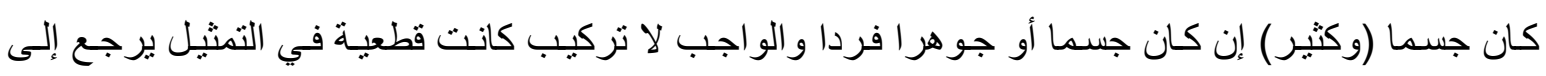
القياس ويفيد اليقين و عليه بنو كلامهم لكن برد عليه (9V) ويخالف لأجله، يذكر عبد القاهر البغدادي إن هنالك

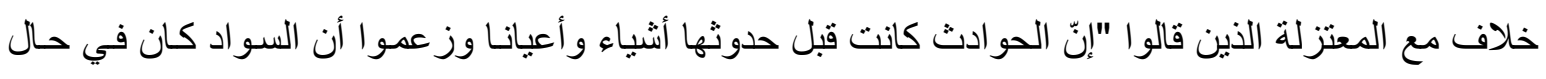
عدمه سو ادا و أثنتو اللمعدوم في حال عدمه كلّ اسم يستحق الموجود لنفسه أو لجنسـه. ومنهم من أثبت الجسم

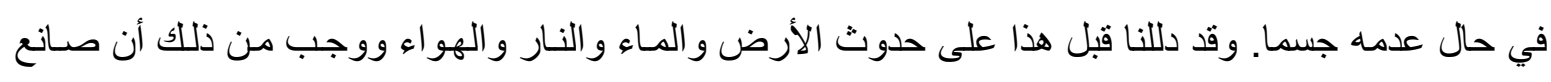

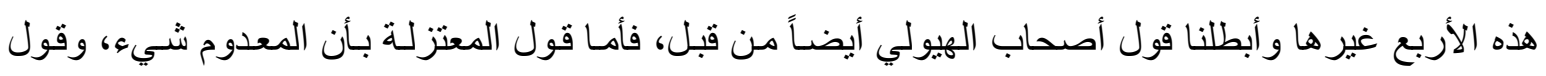

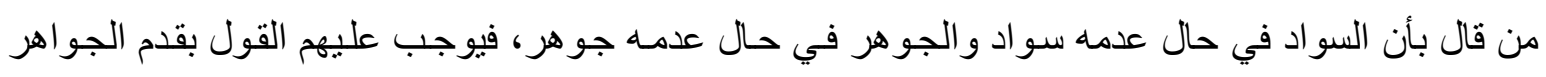
و الأعر اض، لأنهم قد أثنتو الهما في الأزل كل صفة نفسية و الوجود ليس بمعنى زائد على النفس لأن المحدث

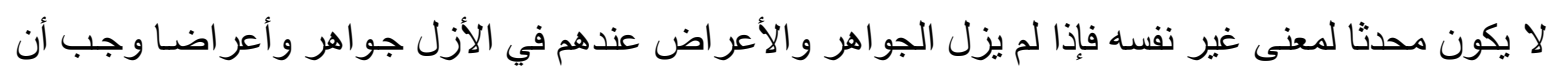

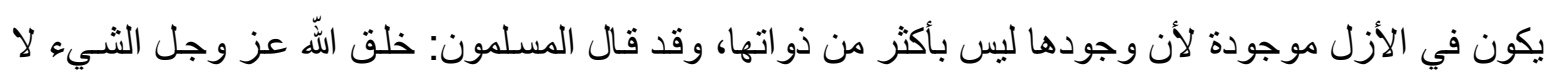

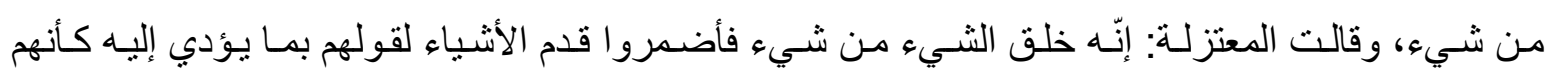

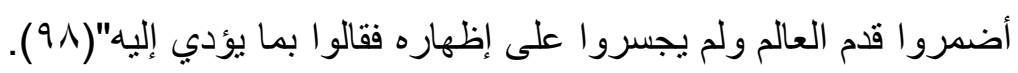

ومن الأمور الأخرى التي رد عليها عبد القـاهر البغدادي هو قول فرقـة من المعتزلة وهي الفرقة

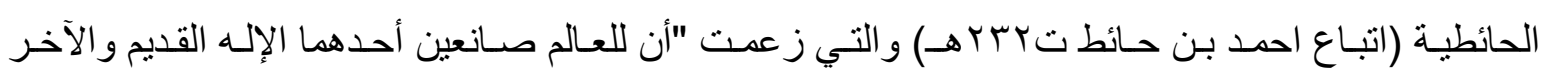
المسيح وهو محدث خلقه اللّ أولاً ثم فوض إليه تدبير العالم وهو الذي يحاسب الخلق في الآخرة [و إنما سمي

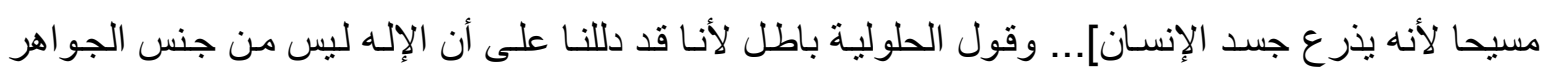
و الأعر اض و لأنه قد ثبت عندنا أنه حي بلا روح فيستحيل وصفه بانتقال روح منه إلى غيره ولو كان الصـانع 
محدثا لافتقر إلى محدث له ولو كان محدثه أيضاً محدثا لافتقر إلى محدث ثالث وهذا يتسلسل لا إلى نهاية و هو محال وما أدّى إلى محال فهو محال وصح باستحالة ذلك وجوب كون الصانع قديما"(99).

ج.النظــام أو العلة الغائية:

هو من الأدلـة التي راجت عند المتكلمين سواء عند المعتزلـة أو سواهم والداليل يقوم على النظسام الموجود في العالم فأول ما يلفت نظر العاقل "عندما يتأمل الكون هو هذا النظام السائد فيه، والنظام لا يحصل

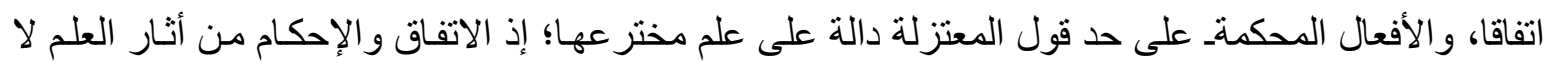
محالة، و إذا كان الفعل صسادر ا من فاعل متقن فيجب أن يكون من آنار علم ذلك الفاعل. و العقل يدرك هذا

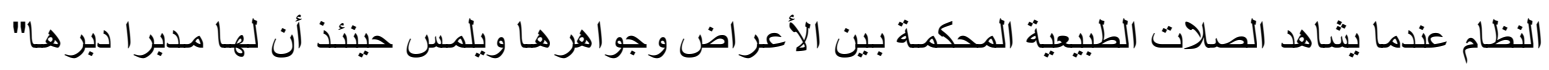
( · ( ). قال النظام: "إن في الكون بر هانا على وجوده تعالى" ( ( ـ ()، ويقول القاضي عبد الجبار:" البرهـان بالعلة الغائية: ويتمثل في بر هان النظام الموجود منـه الكون، فعندما يدرك العقل النظام، لا بـ أن يدرك أن لـه

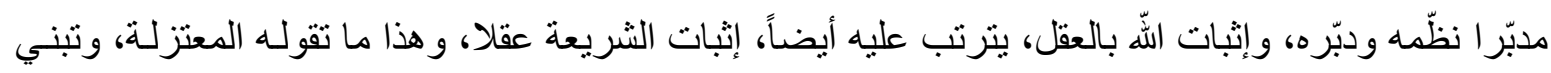

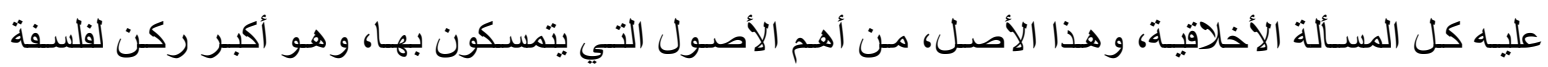

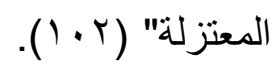

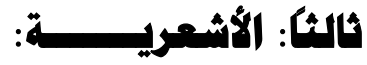

فرقة كلامية إسلامية تنسب إلى أبى الحسن الأشعري علي ابن إسماعيل الذي يعد نقطة تحول مهـة

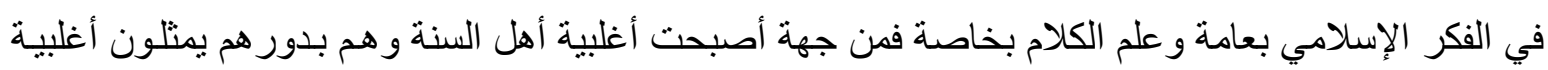
المسلمين تدين بمذهبه ومن جهة أخرى أصبح علم الكلام معترفاً به كعلم من علوم الدين منذ أن استحسن أبو الحسن الخوض فيه وذلك بعد أن كان المحدثون وأئمة الفقه ينفرون الناس من الاقتر اب منه (ب ـ ( ). ابتـدأ الأشـعري فيمـا يتعلق بــ( العقائد= الأصـول) معتزليـاً ولكنهـه تخلى وتبّر أ أمـام النساس مـن هذا المذهب ولقد توسع أصحاب السير والتواريخ و الباحثين في ذكر الأسباب التي دفعت أبي الحسن الأشعري إلى

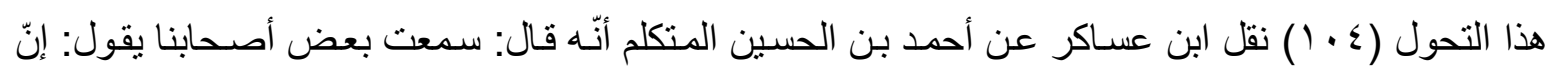

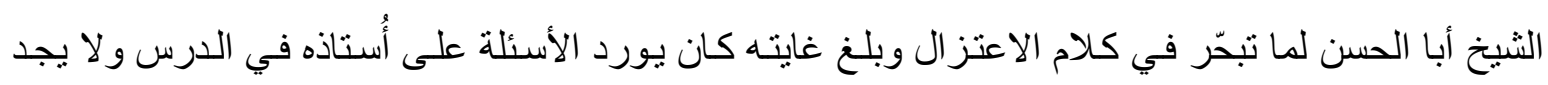
جو اباً شافياً فيتحيّر في ذلك وقد حفظ التاريخ بعض مناظر اته مـع أُستاذه أبي علي الجبائي ومنها: الأشعري: أتوجب على الله رعايـة الصـلاح أو الأصلح في عباده؟ أبو علي: نعم. الأشسعري: مـا تقول في ثناثنة إخوة:

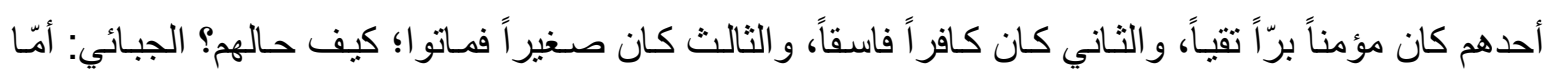
الزاهد ففي الدرجات، وأمّا الكافر ففي الدركات، وأمّا الصغير ففي أهل السـلامة. الأشـعري: إن أراد الصغير

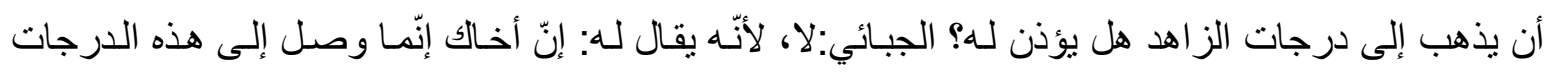
بسبب طاعاته الكثيرة، وليس للك تلك الطاعات. الأشعري: فإن قال ذلك الصغير: التقصير ليس منّي، فإنّّك مـا أبقيتني و لا أقدرتني على الطاعة.الجبائي: يقول الباري جلّ وعلا: كنت أعلم أنّك لو بقيت لعصيت، وصيرت مستحقاً للعذاب الأليم، فر اعيت مصلحتلك. الأشعري: لو قال الأخ الكافر: يا إله العـالمين، كما علمت حاله فقد

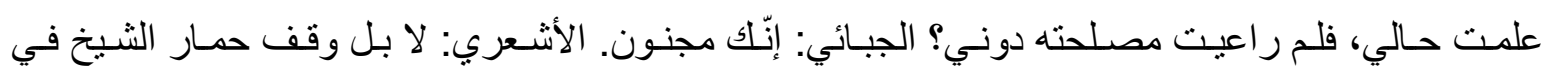


العقبة!! فـانقطع الجبائي (0 ـ (). وبانقطاع الجبائي في هذه المنـاظرة وفي غيرهـا انقطعت صـلة الأشعري بالمعتزلة وبعقائدها واخذ يتلمس الطريق لتكوين فرقة كلاميـة إسلامية جديدة في الظـاهر و التوجها ولكنها لم تتخلص تماماً من اثار المعتزلة سواء التقت الأشعري إلى ذلك أم لم يلتفت.

\section{1.منـمبية الاشا عرة في تهصيل الدليل المؤدي إلى معرفة الله:}

يرى عبد الملك الجويني صـاحب كتاب (الثـامل في أصول الدين) وهو من الاشعرية إن "النظر

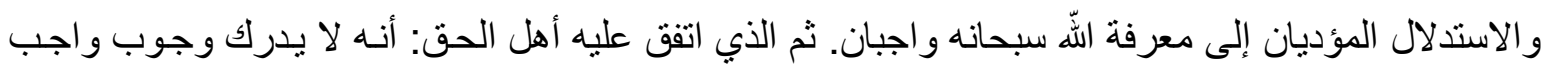
في حكم التكليف عقلا، ومدارك موجبات التكليف الثرائع، و لا نتوصل بقضية العقل قبل استقرار الثريعة إلى ولى درك واجب و لا حظر و لا مباح ولا ندب" (7 ا ) إمـا حسن بن عبد المحسن أبي عذبه (القرن الثاني عشر الهجري) صـاحب كتـاب (الروضـة البهيـة فيهـا بين الاشـاعرة و الماتريديـة) فيؤكد نفس هذا الأمـر بقوله: أنّ معرفة اللّه تعالى هي واجبة بالثرع عند الأشعري و الثشريعة هي مـا شـرعه اللّه تعالى لعباده من الدين قال اللّه

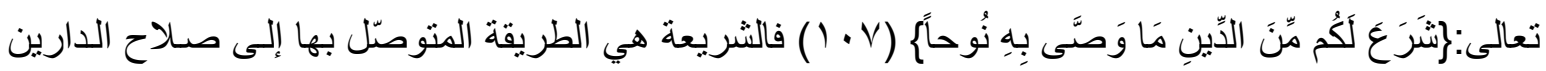

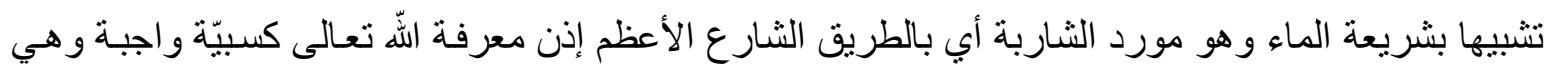
تجب بالدليل السّمعي قال الأشعري إنما تجب بالدليل السّمعي لا العقلي. أمّا وجوبها بالدليل السّمعي فلأنّهـه ورد

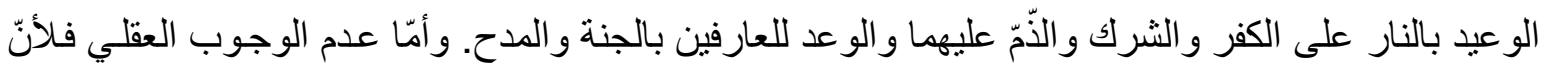

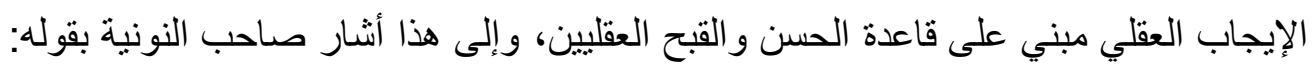

يقول ذلك شر عة الديّـــــان ووجوب معرفة الإله الأشعريّ

إدراك لا حكم على الحيوان

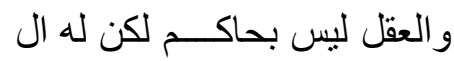

كتب الفروع لصحبنا قو لان وقضوا بأنّ العقل بوجبها وفـي أي العقل ليس بحاكم بالأحكام التكليفيـة الخمسـة، أعني الوجوب و الندب و الإباحسة و الكر اهـة و الحرمة

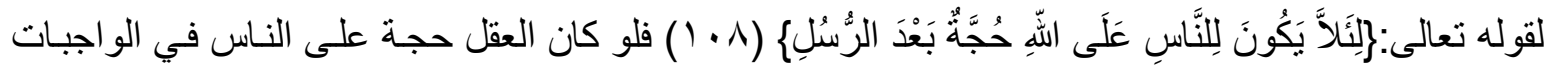

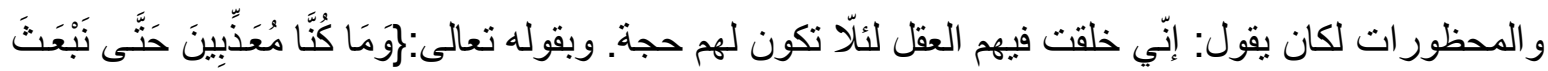

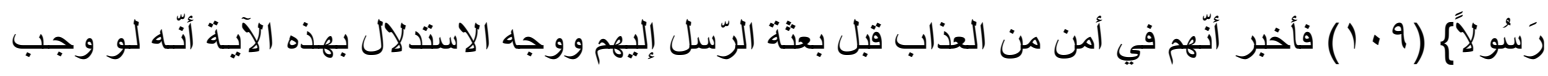
الإيمان بالعقل لوجب قبل البعثة لوجود العقل قبلها ولو وجب قبلها لوجب أن بعاقب بالترك لكن الملزوم وهو

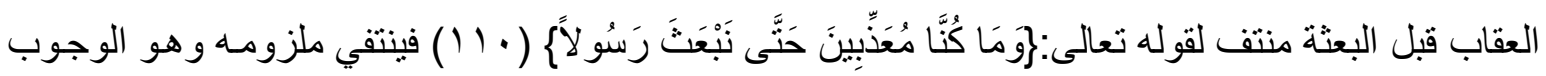

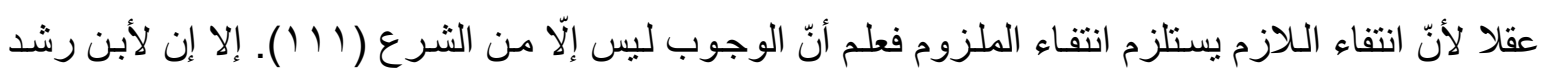

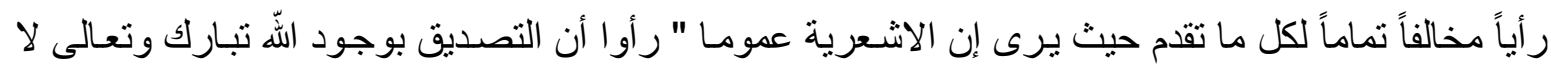

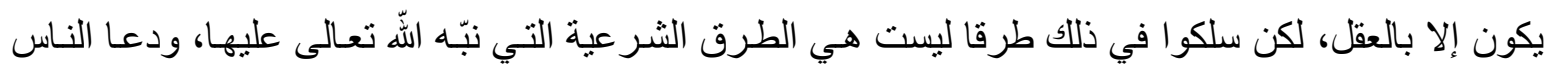

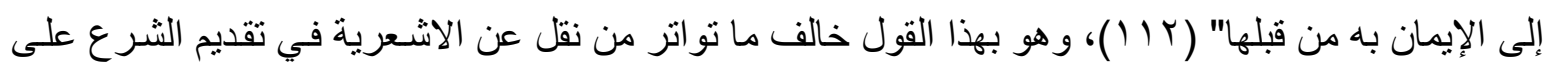
العقل في جملة أرائهم ومن ضمنها معرفة الله تعلىلى، ولعل السبب هو سبطرة النزعة العقلية على ابن رشد باعتباره فيلسوف ويرفع من شان العقل، أو لتوجهه العام وتبنيه لمشروع التوفيق ما بين( الثريعة = الدين) وو(الحكمة = الفلسفة)، فلا إنكال إن قدم احد الطرفين على الأخر في المعرفة باعتبار إن هناك اتصـال مـا بين 
t.أدلـتهم فيى إثبات وجــــــود الله:

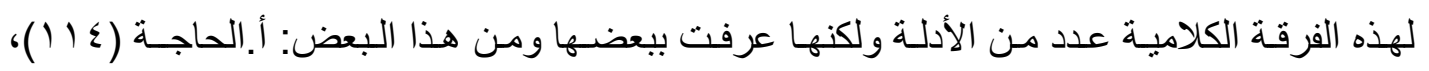

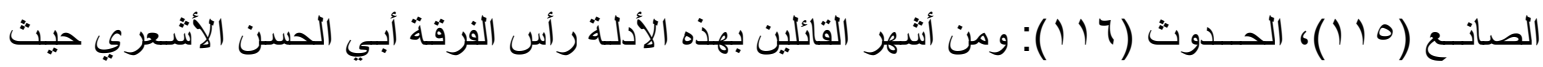
ذكر ها مجتمعة في نص و احد في كتابه (اللهع في الرد على أهل الزيغ و البدع) حيث قال:"إن سـأل سـائل فقال: ما الدليل على أن للخلق صانعاً صنعها ومدبراً دبره. قيل الدليل على ذلك أن الإنسـان التّذي هو في في غايـة الكمال و التمام كان نطفة ثم علقة ثم مضغة ثم لحماً و عظماً ودماً. وقد علمنا أنه لم ينقل نفسه من حسال إلى حسال

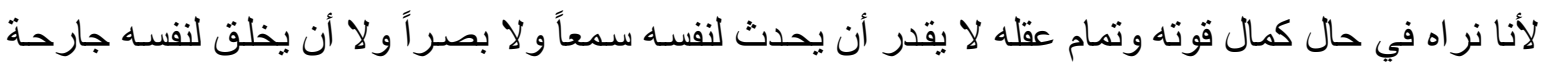
يدل ذلك على أنه في حال ضـعفه ونقصـانه عن فعل ذللك أعجز لأن مـا قدر عليه في حسال النقصـان فهو في حال الكمال عليه أقدر وما عجز عنه في حال الكمال فهو في حسال النقصـان عنه أعجز . ور أينـاه طفلاً ثم شـاباً كهلاً ثم شيخاً وقد علمنا أنه لم ينقل نفسه من حال الثباب إلى حال الكبر والهرم لأن الإنسـان لو جهد أن يزيل عن نفسه الكبر و الهرم ويردها إلى حال الثباب لم يمكنه ذلك فدل ما وصفنا على أنه ليس هو التّذي ينقل نفسـه في هذه الأحوال وأن له ناقلاً نقله من حال إلى حال ودبره على ما هو عليه لأنه لا يجوز انتقاله من حال إلى هـ هـ

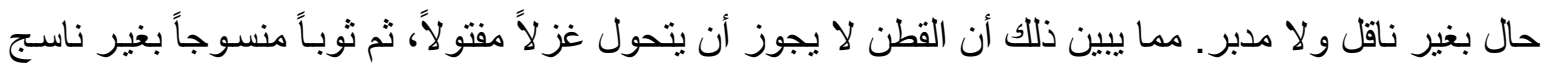
و لا صانع ولا مدبر، ومن اتخذ قطناً ثم انتظر أن يصير غزلاً مفتو لاً ثم ثوباً منسوجاً بغير صـانع ولا ناستج

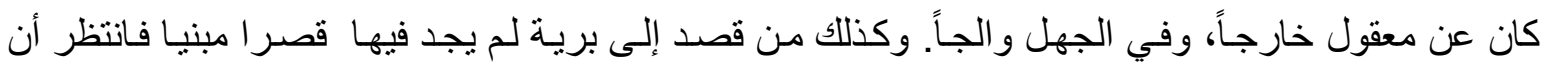
يتحول الطين إلى حالة الآجر وينتضد بعضـه على بعض بغير صـانع ولا بـان كان جـاهلاً، و إذا كان تحول

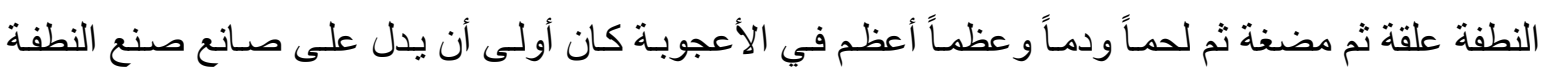

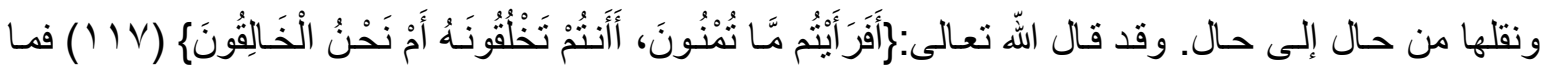
استطاعو ا أن يقولو ا بحجة أنهم يخلقون ما يمنون مع تمنيهم الولد فلا يكون ومـع كر اهتهم لـه فيكون. وقد قـال

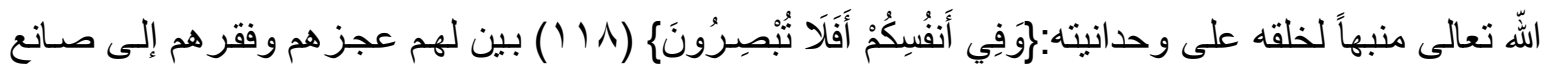
صنعهم ومدبر دبر هم. فان قالو ا: فما يؤمنكم أن تكون النطفة لم تزل قديمة. قيل لهم: لو كان ذلك كما ادعيتم لم

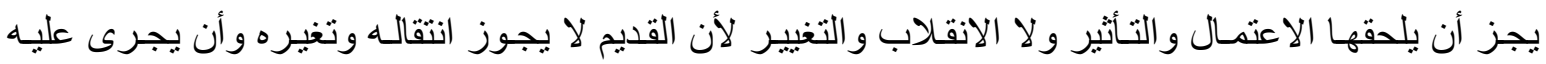

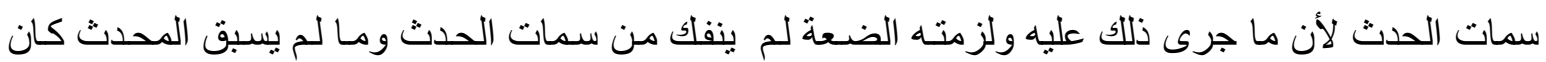
محثثا مصنو عا فبطل بذلك قدم النطفة و غير ها من الأجسام" (9 1 ( ). ويرى محمد عبد الهادي أبو ريدة إن هيكلية الدليل مبنيـة على" آيـات القران التي تتكلم عن الإنسـان وتطوره في مر احل الخلقة وهو هنا في صورة دليل نظري ينبنى على مقدمة حسية (تطور الإنسان) ومقدمة ترجع إلى المشاهدة النفسية (علم الإنسان من نفسه بأن ليس هو الذي ينقل نفسـه من طور إلى طور) ونتيجـة استدلالية هي أنه لابد أن يكون لـه ناقل ينقله من حال إلى حال" ( • I ). إما الثيخ جعفر السبحاني فيرى" أولاً أنّ الاستدلال المذكور استدلال عقلي بحت، ومعتمد على أصل فلسفي وهو حاجـة الممكن إلى العلة، أو

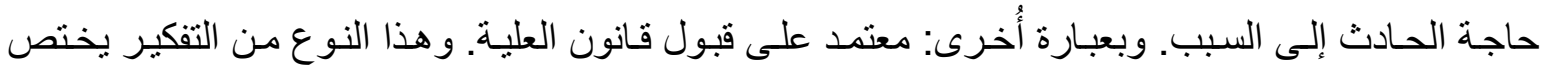

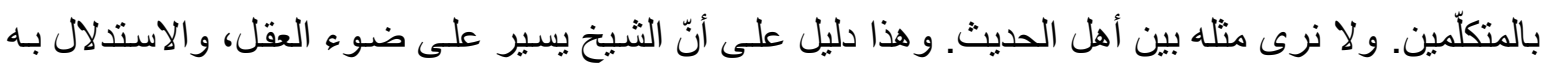


ما أمكن. ثانياً: أنّ صلب البرهان في البيان الأوّل يرجع إلى أنّ فاقد الكمال لا يعطيه، فالإنسـان إذا عجز عن إحداث السمع والبصر في حال القدرة، فهو في حال العجز أولى...

ثالثاً: أنّ ما استعرض الثيخ من الآيتين إنّما هو من الثوا اهد الواضحة على أنّ القرآن يعتمد في بيـان

الأُصول والمعارف على الأدلة العقليّة والبر اهين الواضحة، من أجل إقناع عامـة البشر، مؤمنـاً كان أم كافراً،

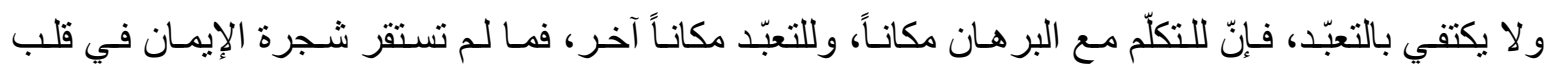

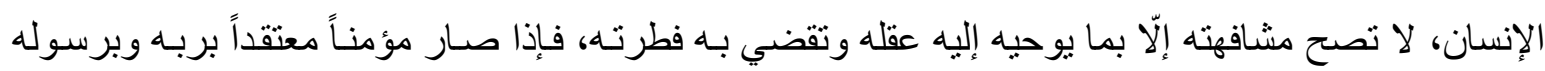

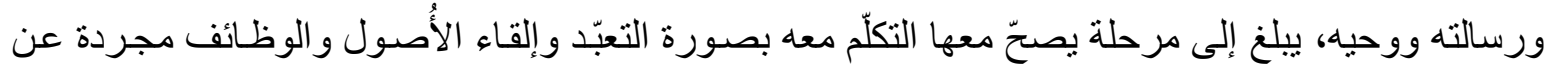

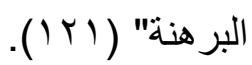

\section{ب.الجوهــر الفُرد أو الجــز ء الذي لا يتجزاً (1HN):}

من أشهر أدلة الاشعرية وهو كما أرى نتيجة منطقية أو متطورة للقول بحدوث العالم باعتبار أنهم قد ربطو اوجود الله ببحوثهم الطبيعية حيث يعتمدون في ذلك على دليل حدوث العالم (Tr I ) الذي استفاد منهـ

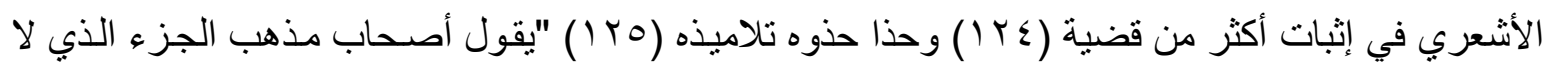

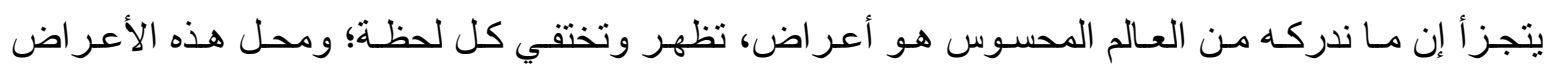
المتغيرة هو الجواهر(الجسمية)، وهذه الجواهر لا يمكن أن نعتبر هـا غير متغيرة، لأنها محل للمتغيرات في

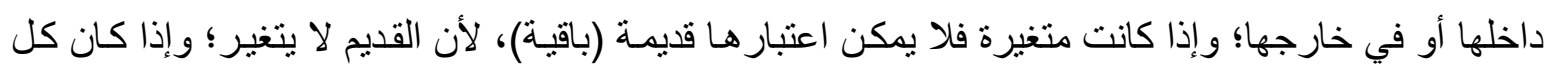

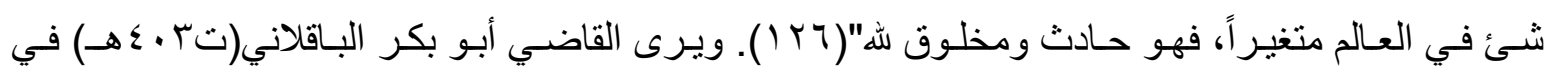

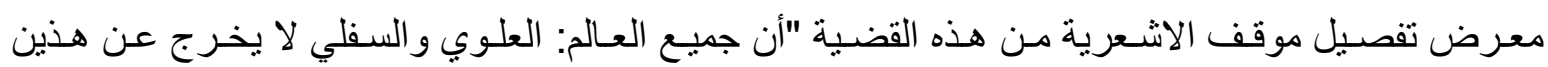
الجنسين، أي الجوا اهر والأعر اض. وهو محدث باسره، وذلك لأن الأعر اض حوادث، والدليل على حدوثها هو بطلان الحركة عند مجيء السكون، لأنها لو لم تبطل عند مجيء السكون لكانا موجودين في الجسم معـاً،

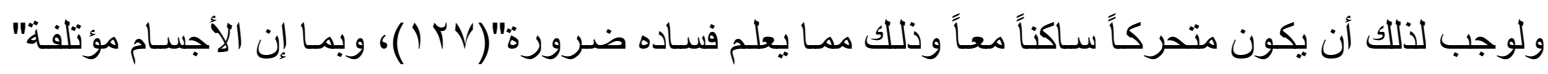

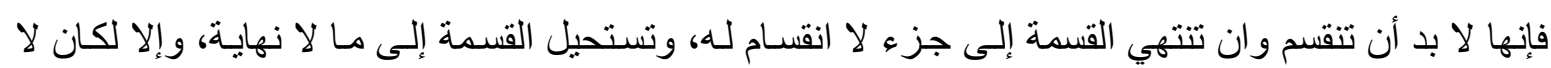
نهاية لما في الفيل وما في النملة من أجزاء ولأدى ذلك إلى ألا يصبح الفيل أكبر من النملة"( ب ( ). إما الغزالي (ته .0.0ـ) فلقد قرر هذا الأمر من خـلال فصـله مـا بين الله والعالم فيقول: العـالم كل موجود سوى اللّه تعالى. ونعني بكل موجود سوى اللّ تعالى الأجسـام كلها و أعر اضـها، وشرح ذلاّلك بالتفصيل أنا لا نشك في أصل الوجود، ثم نعلم أن كل موجود إما متحيزا أو غير متحيز ، وأن كل متحيز إن لم يكن فيه ائتلاف فنسميه جو هرا فردا، و إن ايتّلف إلى غيره سميناه جسما، وإن غير المتحيز إمـا أن يستدعي وجوده

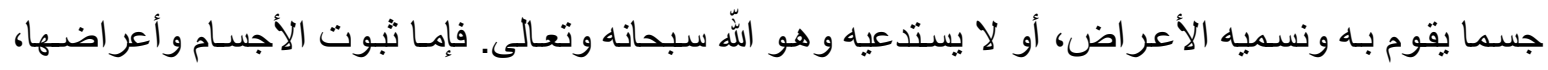

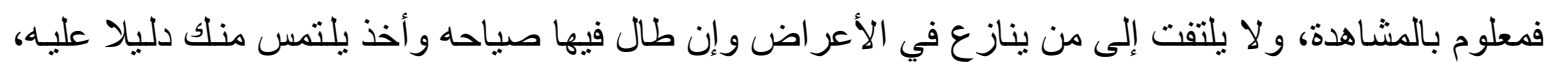
فإن شغبه ونز اعه و التماسه وصياحه، إن لم يكن موجودا فكيف نشتغل بالجواب عنه و الإصغاء إليه، و إن كان موجودا فهو لا محالة غير جسم المنازع إذ كان جسما موجودا من قبل، ولم يكن التنازع موجودا فقد عرفت

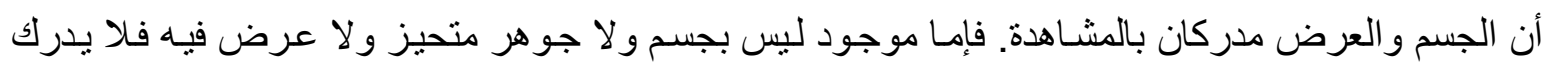


بالحس ونحن ندعي وجوده وندعي أن العالم موجود به، وبقدرته، وهذا يدرك بالدليل لا بالحس" (9 ب ا ). وقد فند ابن رشد ما ذهب إليه الاشعرية في القول بـالجزء الذي لا يتجزأ (الجوهر الفرد) وملحقات هذه النظريـة حيث قال:"وطريقتهم التي سلكوا في بيان حدوث الجزء الذي لا يتجزأ، وهو الذي يسمونه الجوهر الفرد، طريقـة معتاصـة، تـذهب على كثير مـن أهل الرياضــة (=المدربين، المـاهرين) في صـنـاعة الجدل (= فـن الجدل= علم الكلام)، فضـلا عن الجمهور. ومـع ذلك فهي طريقة غير برهانية ولا مفضية بيقين إلى وجود الباري سبحانه. و وذلك أنه إذا فرضنا أن العالم محدث لزم، كما يقولون، أن يكون له ولا بد، فاعل محدث. ولكن يعرض في وجود هذا المحدث شك ليس في قوة صناعة الكلام الانفصـال عنهـ. وذلك أن هذا المحدث لسنا نقدر أن نجعله أزليا و لا محدثا. أما كونه محدثا. فلأنه يفتقر إلى محدث، وذللك المحدث إلى محدث، ويمر الأمر إلىى غير نهايـة، وذللك مستحيل. وأمسا كونـه أزليا فإنهـ يجب أن يكون فعله المتعلق بـالمفعو لات أزليا، فتكون المفعو لات أزلية. و الحادث يجب أن يكون وجوده متعلقا بفعل حادث. اللهم إلا لو سلموا أنه يوجد فعل حادث عن فاعل قديم، فإن المفعول لابد أن يتعلق بـه فعل الفاعل. وهم لا بسلمون ذلك. فـإن من أصولهم أن المقارن للحو ادث حادث"( • ( ) ).

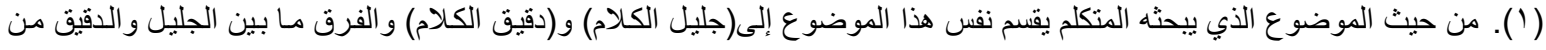

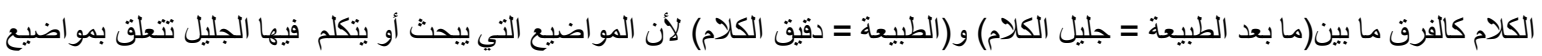

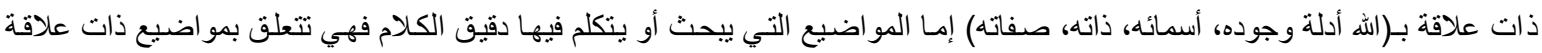

بـ(الجسم، والسكون و الحركة، الدولة، الإمامة، الرزقة).

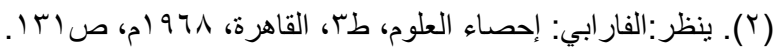

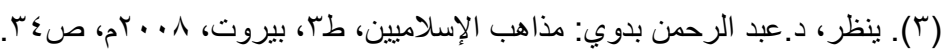

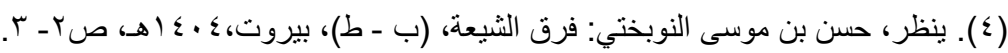

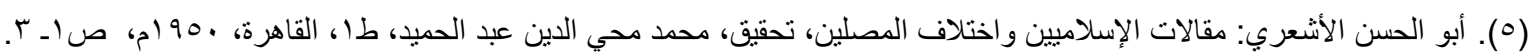

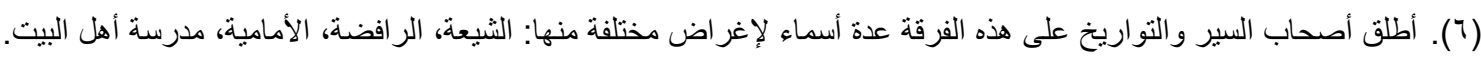

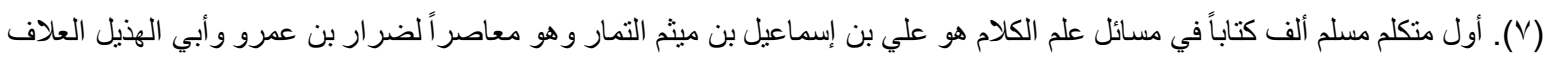

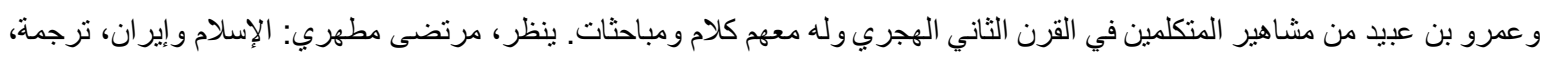

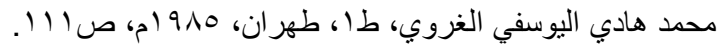

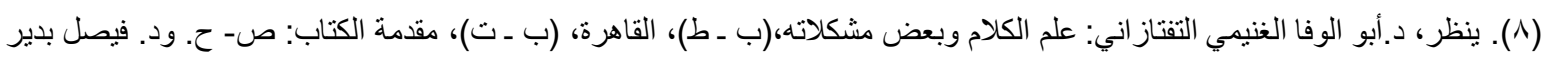

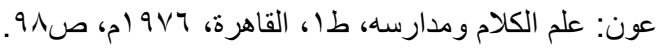

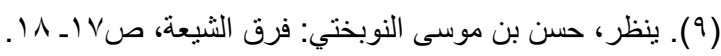

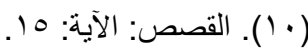

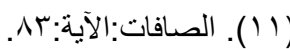

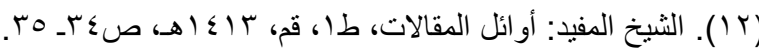

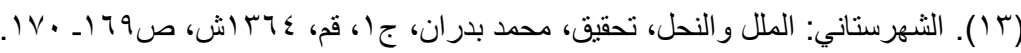

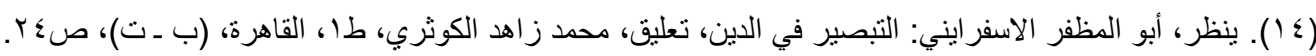

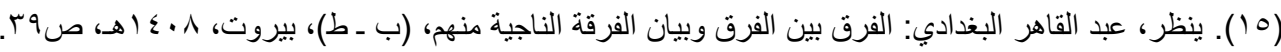

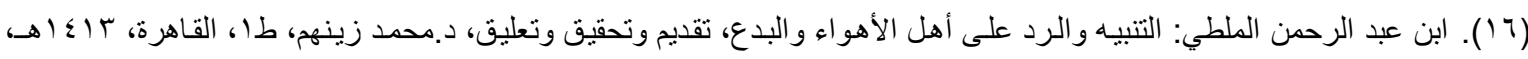




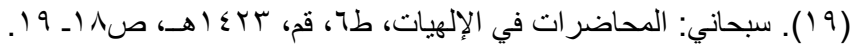

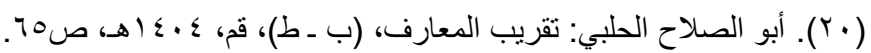

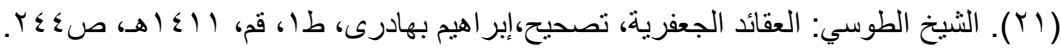

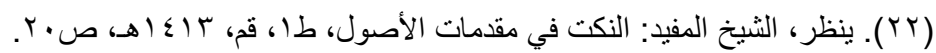

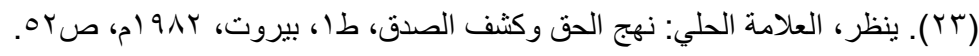

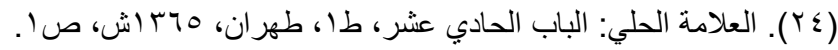

(Yo)

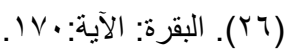

(YV)

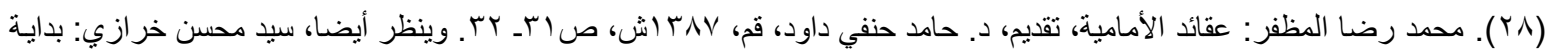

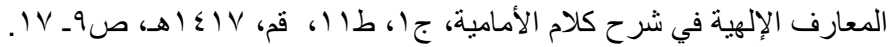

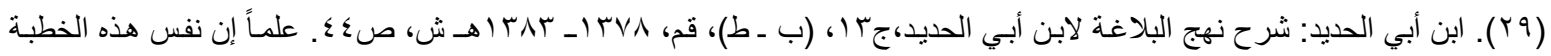
وردت بالألفاظ أخر في شرح الثيخ محمد عبده. ينظر، من مختار ات الثريف الر اضى من كلام سيدنا الإمام علي بن أبي طالب، شرح، لشيخ

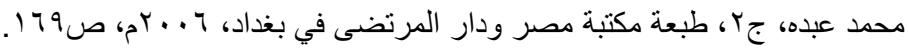

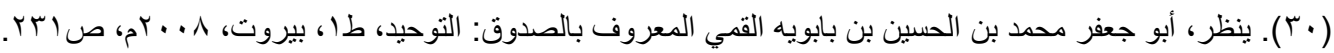

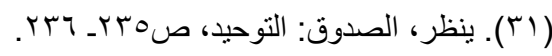

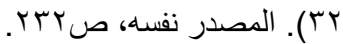

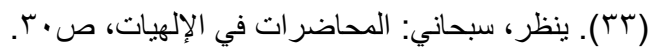

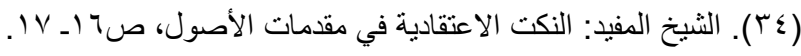

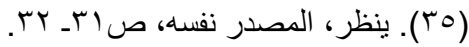

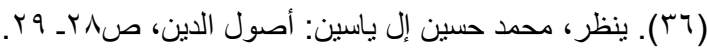

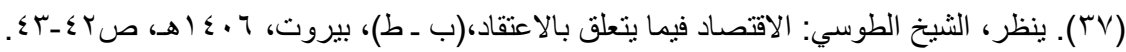

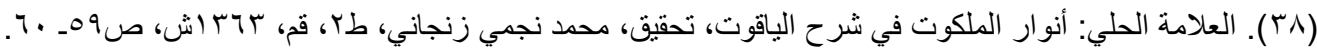

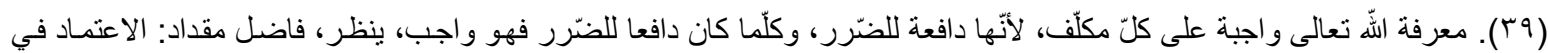

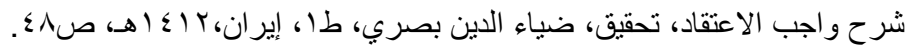

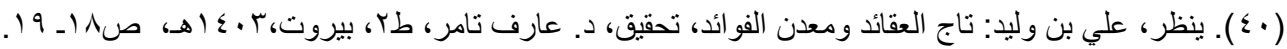

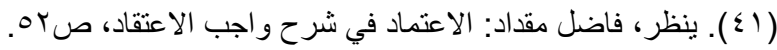

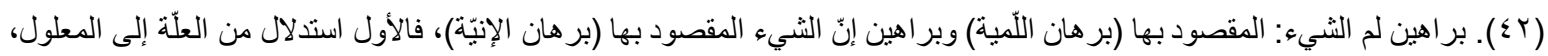

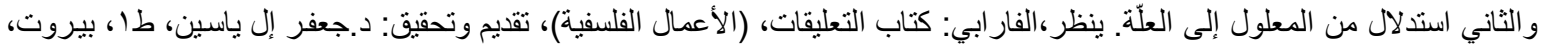

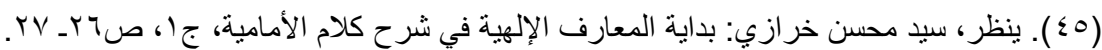

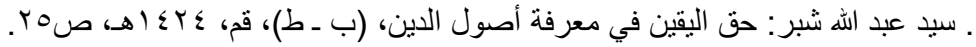

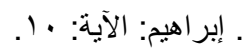

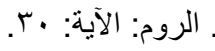

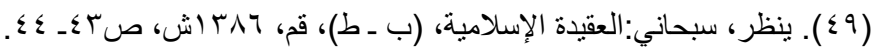

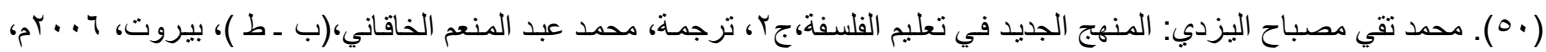

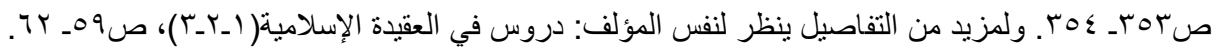

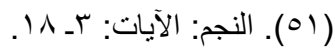

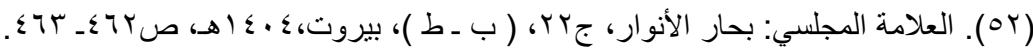

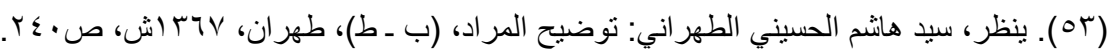


7 70 (0)

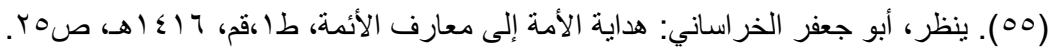

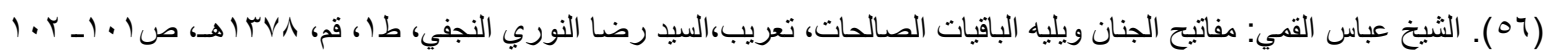

(دعاء زمن الغيبة).

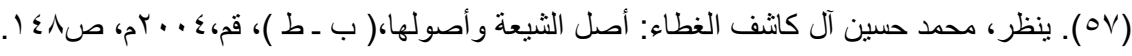

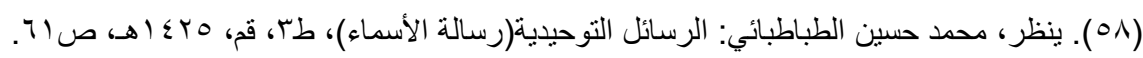

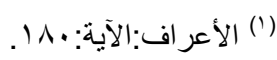

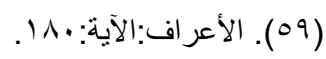

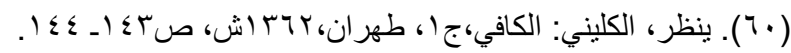

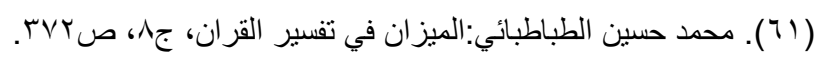

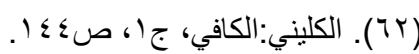

( آ ). من الو هلة الأولى قد لا يوجد تر ابط ما بين موضوع الأدلة التي قدمها المعتزلة لإثبات وجود الله مع هذا المطلب و الذي يبحث في نشأة

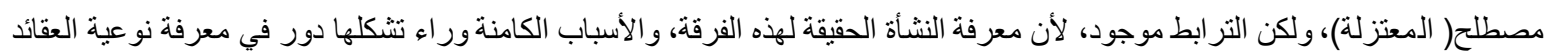

التي تطرح وتقدم، وفي هذه الدائرة تقدم عدة فرضيات منها (سياسية، عقائدية، معرفية)، ولسوف نناقش بعضها في المنن.

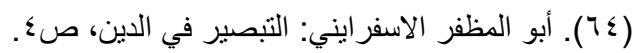

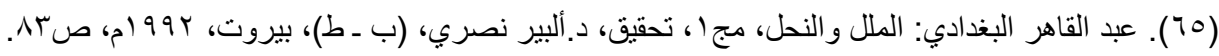

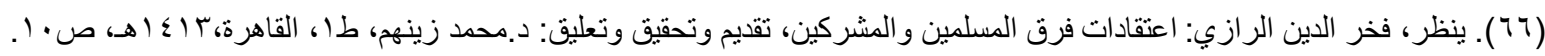

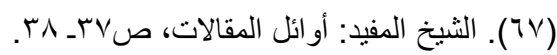

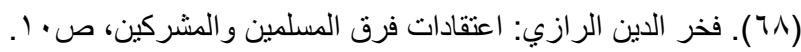

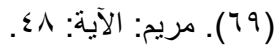

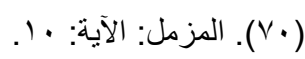

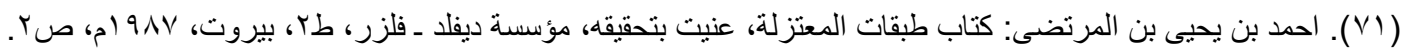

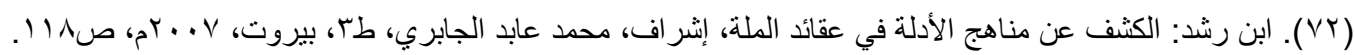

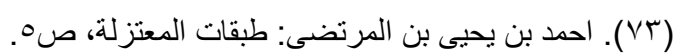

( ع (V). تباين القوم من المتقدين في عدد فرق المعتزلة، ومن الحكم عليهم، فذهب(الثهرستاني)، إلى إن عدد فرقهم إلى اثتني عشرة فرقة.

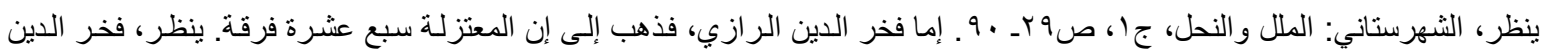

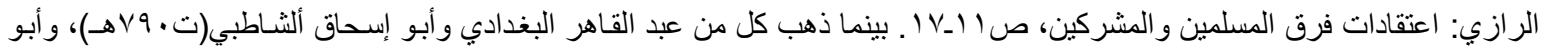
المظفر الاسفرايني(ت (V§ هـ)، إلى إن المعتزلة عشرين فرقة، وزاد أبو المظفر الاسفرايني على المتقدمين قوله: إن كل فريق منهم يكفر

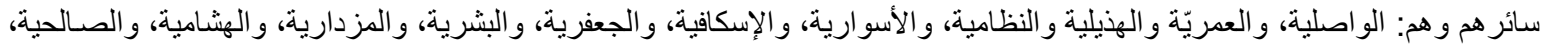

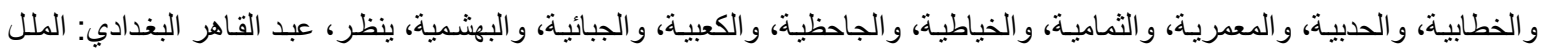

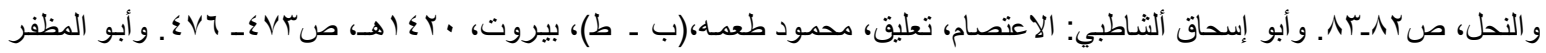

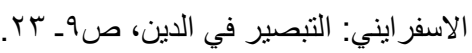

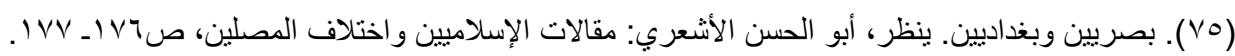

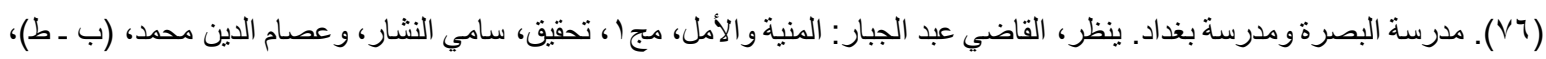

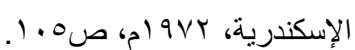

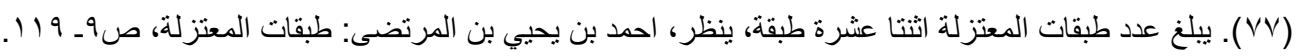

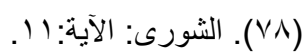

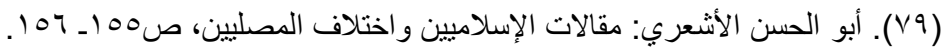

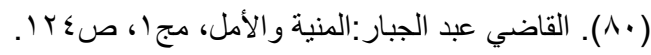

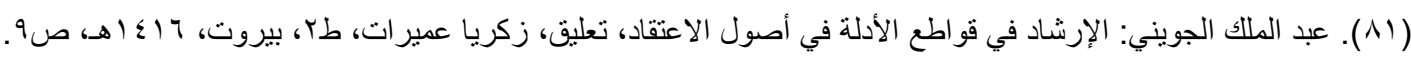

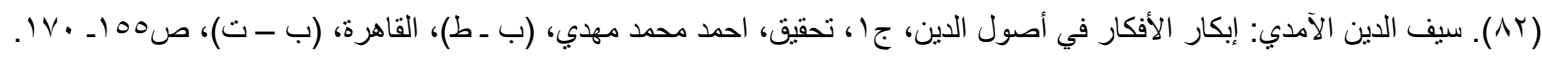




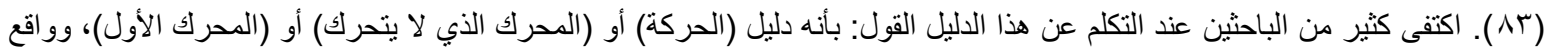

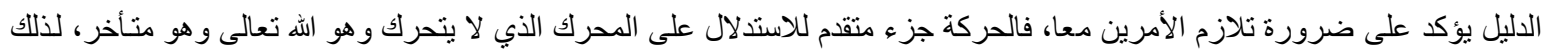

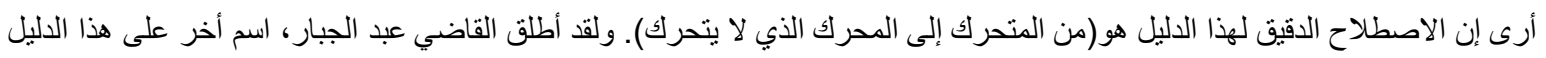

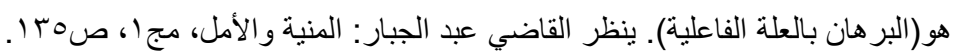

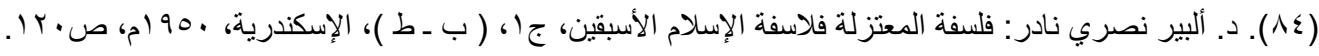

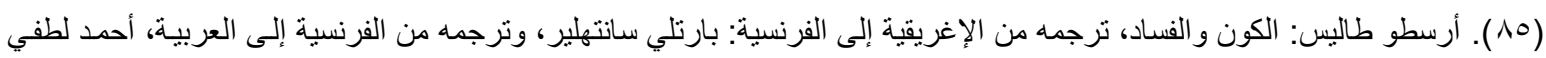

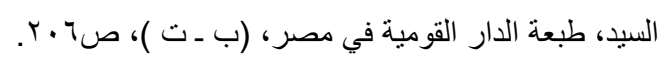

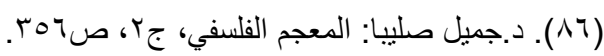

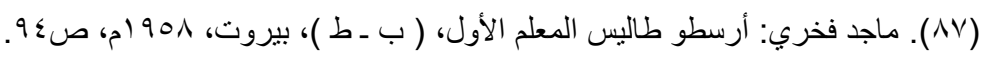

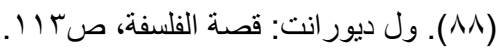

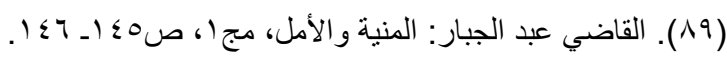

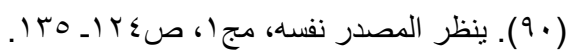

( (9). يرى مؤلف كتاب(الكامل في الاستقصاء من كلام القدماء)، وهو من المعتزلة بان المعتزلة وحدهم من قال بدليل الحدوث خلافاً للفلاسفة

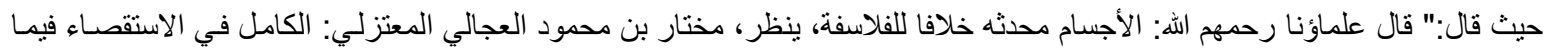

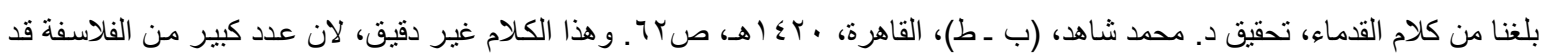
استذل على وجود الله نعالى بهذا الدليل ومنهم الكندي. (ז (9). هذه الدعوى غير دقيقة، وقد بيناها عندما تكلمنا عن أدلة وجود الله عند الثنيعة، وكيف إن هذا الدليل كان حاضر أَ، في خطب الإمام علي

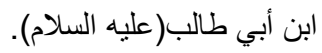
( (ب) ). إبر اهيم بن محمد بن احمد المؤيدى: الإصباح على المصباح في معرفة الملك الفتاح، تحقيق، عبد الرحمن شايم، طا، صنعاء،

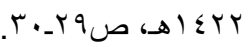

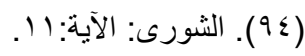

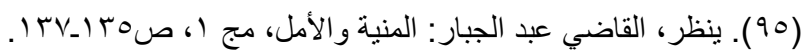

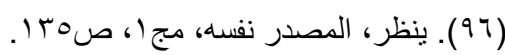

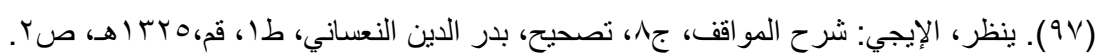

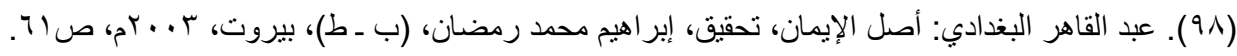

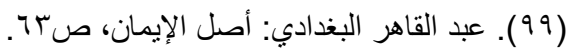

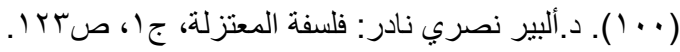

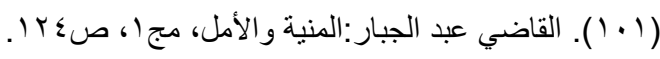

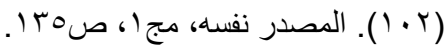

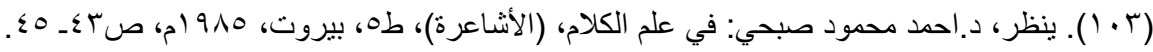

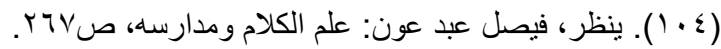

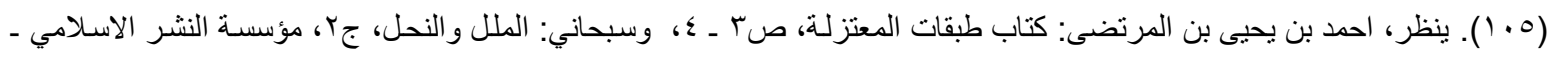

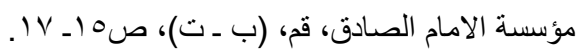

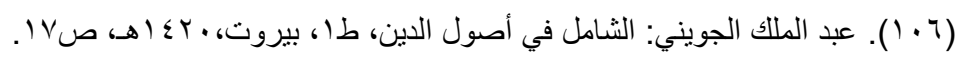

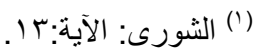

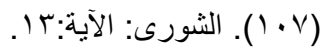

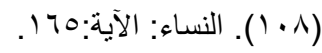

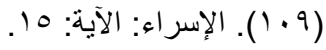

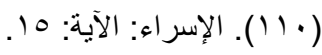

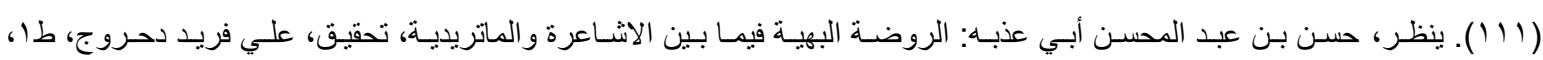

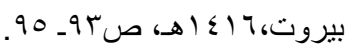




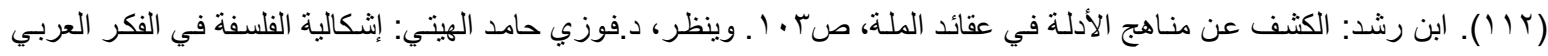

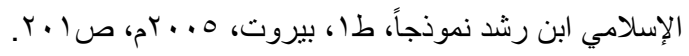

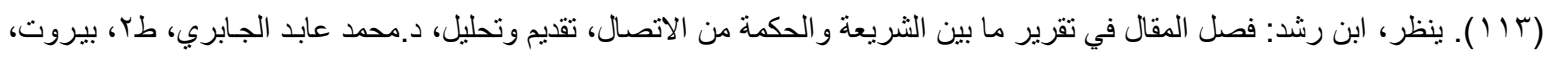

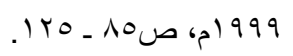

( ( (1). بمعنى إن الموجودات كل الموجودات بحاجة إلى الله في وجودها، لأنها مفتقرة في وجودها إليه، فهو الغني وهي الفقيرة المحتاجة.

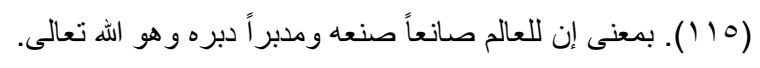

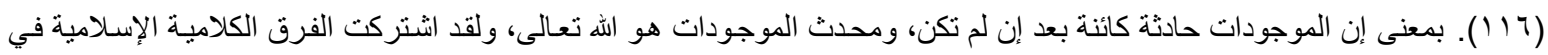

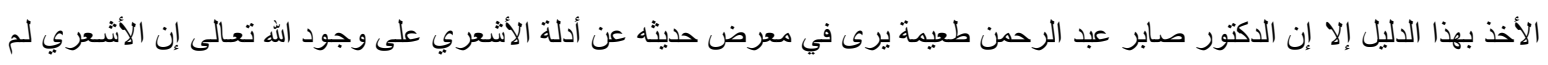

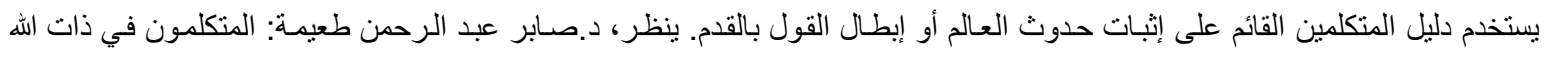

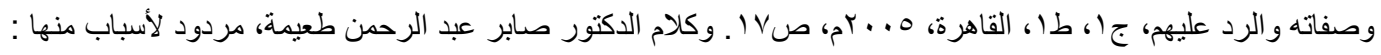

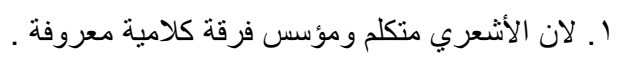

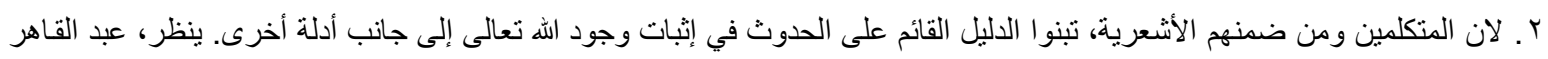

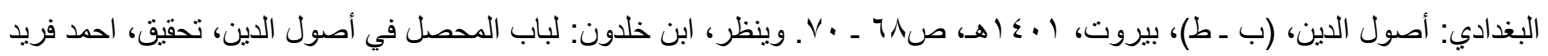

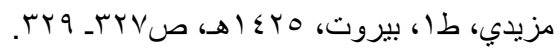

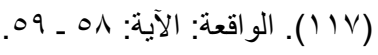

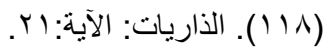

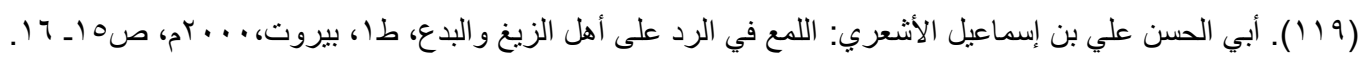

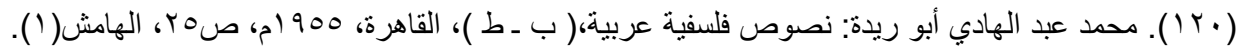

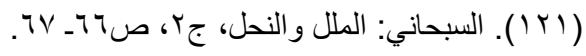

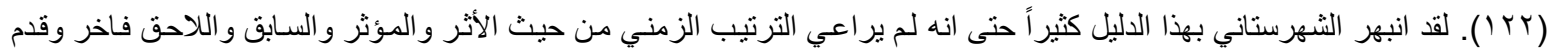

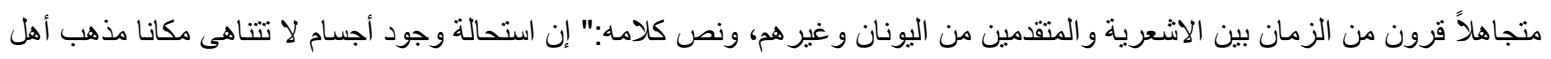

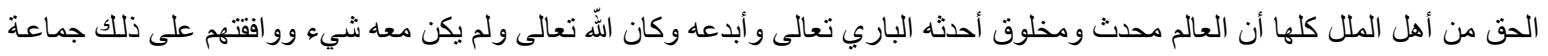

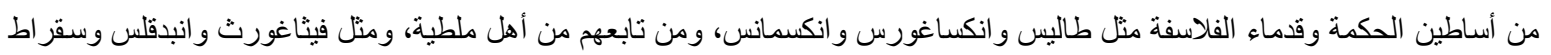

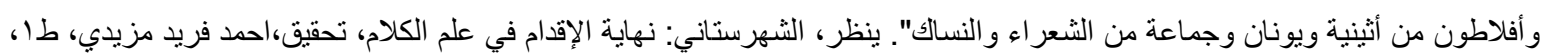

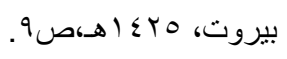

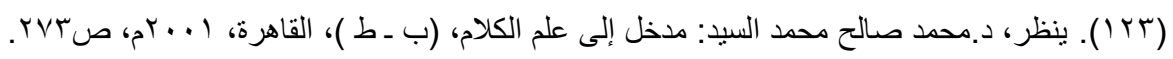

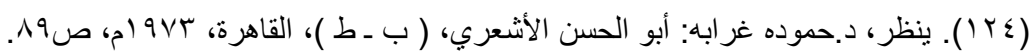

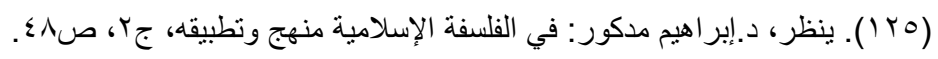

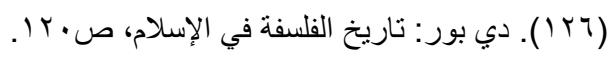

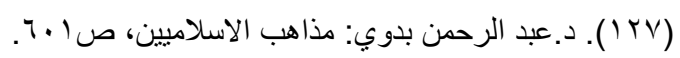

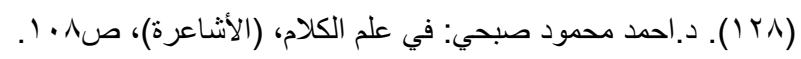

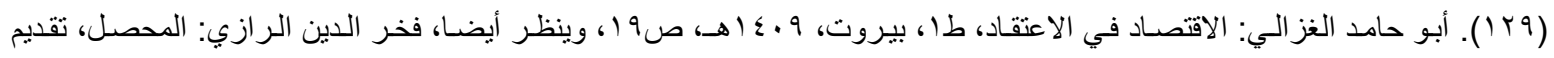

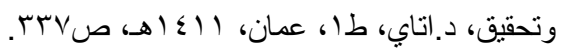

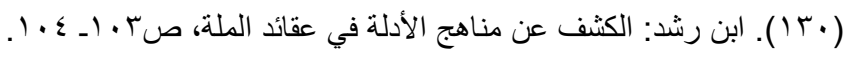

